\title{
THE PALEO-ANTHROPOCENE AND THE GENESIS OF THE CURRENT LANDSCAPE OF ISRAEL
}

\author{
OREN ACKERMANN ${ }^{1 *}$, AREN M. MAEIR ${ }^{2}$, SUEMBIKYA (SUE) FRUMIN $^{2}$, \\ TAL SVORAY $^{3}$, EHUD WEISS ${ }^{2}$, HELENA M. ZHEVELEV ${ }^{4}$, LIORA KOLSKA HORWITZ ${ }^{5}$ \\ ${ }^{1}$ Israel Heritage Department and the Department of Land of Israel Studies and \\ Archaeology, Ariel University, Israel, P.O.B. 3, Ariel 4070000 \\ ${ }^{2}$ The Martin (Szusz) Department of Land of Israel Studies and Archaeology, Bar-Ilan \\ University, Israel \\ ${ }^{3}$ Department of Geography and Environmental Development, Ben-Gurion University of the \\ Negev, P.O.B. 653, Beer-Sheva, 84105 Israel \\ ${ }^{4}$ The Laboratory of Geomorphology and Soil, The Department of Geography and \\ Environment, Bar-Ilan University, Ramat Gan, 52900 Israel.Helena.Zhevelev@biu.ac.il \\ ${ }^{5}$ National Natural History Collections, Faculty of Life Sciences, The Hebrew University, \\ Jerusalem, Israel \\ *The first draft of this paper was written when O.A. was a staff member at Ashkelon \\ Academic College and at Bar-Ilan University, corresponding author: orenack@gmail.com
}

Received: $12^{\text {th }}$ August 2017, Accepted: $30^{\text {th }}$ November 2017

\section{AbSTRACT}

Worldwide, human impact on natural landscapes has intensified since prehistoric times, and this is well documented in the global archaeological record. The period between the earliest hominids and the Industrial Revolution of the late $18-19^{\text {th }}$ centuries is known as the Paleo-Anthropocene. The current study reviews key geoarchaeological, floral and faunal factors of the Paleo-Anthropocene in Israel, an area that has undergone human activities in various intensities since prehistoric times. It discusses significant human imprints on these three features in the Israeli landscape, demonstrating that its current form is almost entirely anthropogenic. Moreover, some of the past physical changes still dynamically shape Israel's zoological, archaeological and geomorphic landscape today. It is hoped that insights from this article might aid in guiding present-day management strategies of undeveloped areas through renewal of human activity guided by traditional knowledge.

Keywords: Anthropocene, Management of Anthropogenic Landscape, Landscape History, Human and Environmental Interaction, Eco-geomorphology, Traditional Knowledge

\section{INTRODUCTION}

The impact humans have on landscape systems, as their designers and modifiers, has increased and accelerated in modern times to the point that today, human activity is perceived as equivalent to a force of nature in shaping the environment (Crutzen, 2002 a,b). Indeed, the scale of human impact on earth system processes is such that humans are currently the 
Ackermann O., Maeir A. M., Frumin S., Svoray T., Weiss E., Zhevelev H.M., Kolska Horwitz L.: The Paleo-Anthropocene and the Genesis of the Current Landscape of Israel

greatest evolutionary and ecological force on the planet. This power is expressed by the great acceleration phenomena (e.g. Steffen et al., 2004; 2015) including global warming, an upsurge in extreme flood events and the creation of alternative water cycles (Grassel, 2006; Macklin et al., 2012), as well as the extinction of species (Leakey \& Lewin, 1996), which was coined the Sixth Extinction by Kolbert (2014). Soil erosion has increased to a level considered a human security hazard for the $21^{\text {st }}$ century (Svoray \& Bensaid, 2010; Svoray et al., 2015; Amundson et al., 2015), and we are witnesses to the creation of a new geological formation 'plastiglomerate', comprising molten plastic (Corcoran et al., 2014).

The unprecedented global scale and broad scope of human impact over the past two centuries has led to a call for the creation of a new geological epoch coined Anthropocene the geology of humankind (Crutzen \& Stoermer, 2000; Crutzen, 2002 a,b). The timing of the epoch's onset is currently under debate, though many have set the late $18^{\text {th }}-19^{\text {th }}$ century Industrial Revolution as its starting point (e.g., Ruddiman, 2003; Balter, 2013; Foley et al., 2013; Braje \& Erlandson, 2014; Voosen, 2016), and the term has yet to be officially accepted by the International Commission on Stratigraphy (ICS; Sample, 2014). However, it has already been adopted de facto by many members of the scientific community, as demonstrated by the establishment of new journals (e.g. "Anthropocene", "The Anthropocene Review", "Elementa: Science of the Anthropocene") and an ever-increasing corpus of publications on this topic.

Numerous studies in the field of environmental archaeology and the paleosciences show that significant environmental changes resulting from anthropogenic activities took place long before the Industrial Revolution (Ruddiman, 2003; Kaplan et al., 2010; Boivin et al., 2016). Accordingly, the term "Paleo-Anthropocene" as the precursor of the Anthropocene, has come into use, denoting the period starting after the appearance of the genus Homo (ca. 2.5million years BP) up until the Industrial Revolution (Foley et al., 2013).

Some key points attesting to significant anthropogenic-derived changes in the prehistoric and historic periods of the world have been noted, amongst them are: earliest intentional utilization of fire $~ 1.0$ million years ago (Berna et al., 2012); extinction of mega-fauna (animals weighing $44 \mathrm{~kg}$ and more) at the end of the Pleistocene epoch (ca. 16,000 years ago); domestication of plants and animals, with the earliest onset in the Near East placed at 12,000 years ago (e.g., Vigne, 2011; Zohary et al., 2012; Smith \& Zeder, 2013), or perhaps, even as early as 23,000 years ago for plants (Snir et al., 2015); development of anthropogenic soils $\sim 2,000$ years ago, (Certini \& Scalenghe, 2011).

Enriching and complementing this global picture, the current paper reviews the Paleo-Anthropocene in Israel as a representative example of the Eastern Mediterranean. This area has undergone intensive human activity from a very early period, $\sim 1.5$ million years ago when the first stone tools where used by hominins (Horowitz et al., 1973), followed by the use of fire in open-air sites 700 or 300 thousand years ago in caves (Goren Inbar et al., 2004; Karkanas et al., 2007). In addition, the archaeology of the area has been studied extensively, offering a well-documented and dated record of human-environmental interactions. Salient examples of events and processes from the Paleo-Anthropocene record of the region are presented here in order to examine the question of whether undeveloped landscapes in Israel today are anthropogenic in origin or natural. Specifically, we review ancient human impacts on the landscape by exploring three main components: the physical platform, floral composition and distribution, and faunal composition and distribution, with reference to studies and records from multiple archaeological disciplines (Table 1). 


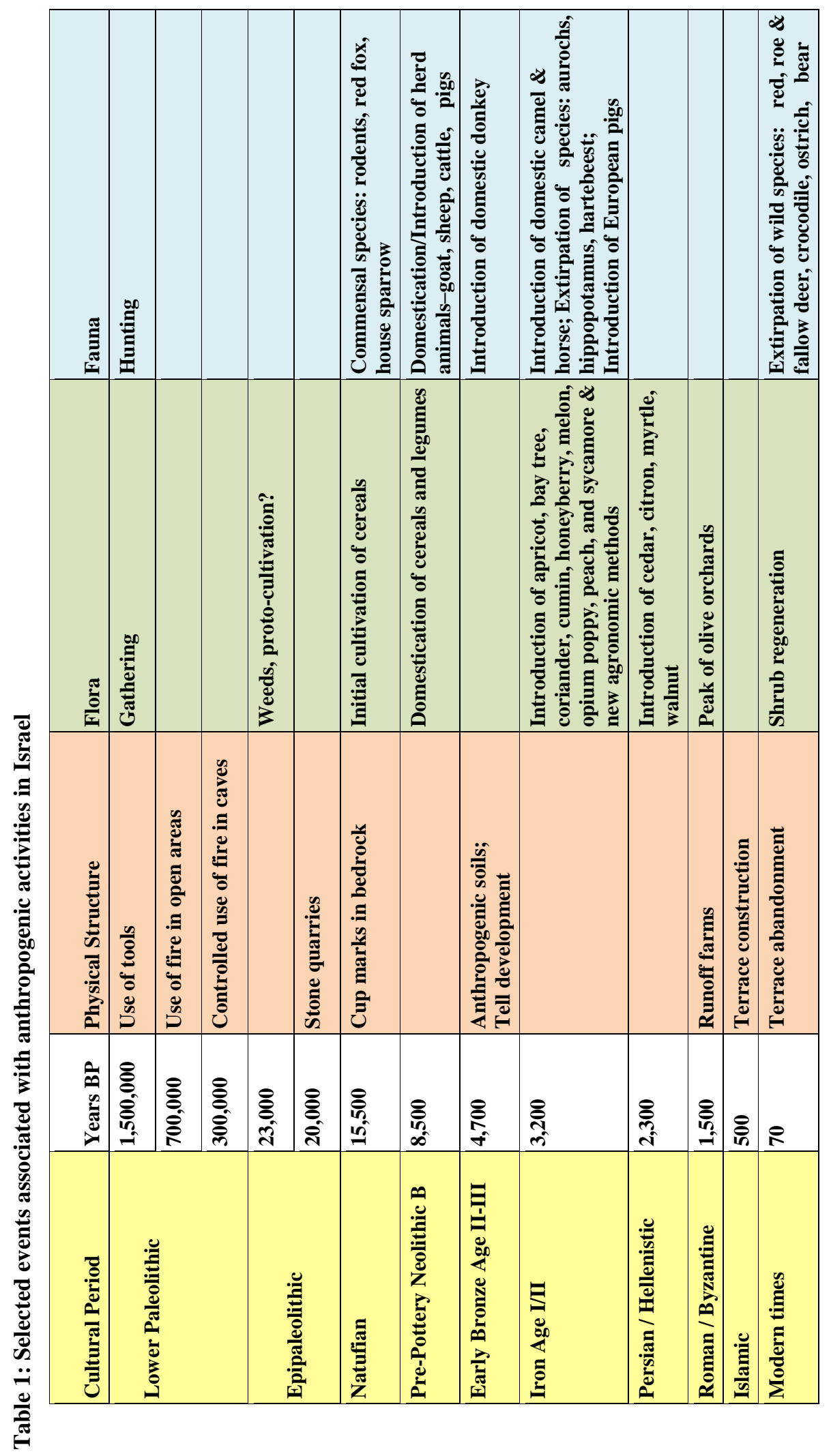


Ackermann O., Maeir A. M., Frumin S., Svoray T., Weiss E., Zhevelev H.M., Kolska Horwitz L.: The Paleo-Anthropocene and the Genesis of the Current Landscape of Israel

\section{BACKGROUND}

Israel is located in the Eastern Mediterranean (Fig. 1a) and runs along the transitional climate zone between the sub-humid Mediterranean climate in the north and semi-arid regions in the south (Fig. 1b, Kafle \& Bruins, 2009). The land hosts four phytogeographic zones: Mediterranean, Irano-Turanian (Asian steppes), Saharo-Arabian (Sahara, Sinai and Arabian deserts) and Sudanian (subtropical savannas of Africa) (Danin, 1988).

\section{Fig. 1: Study area}

a. General map; b. Location of main sites and regions mentioned in the text. $300 \mathrm{~mm}$ isohyet (in red) marks the transition from the sub-humid Mediterranean to semi-arid and arid climate zones.

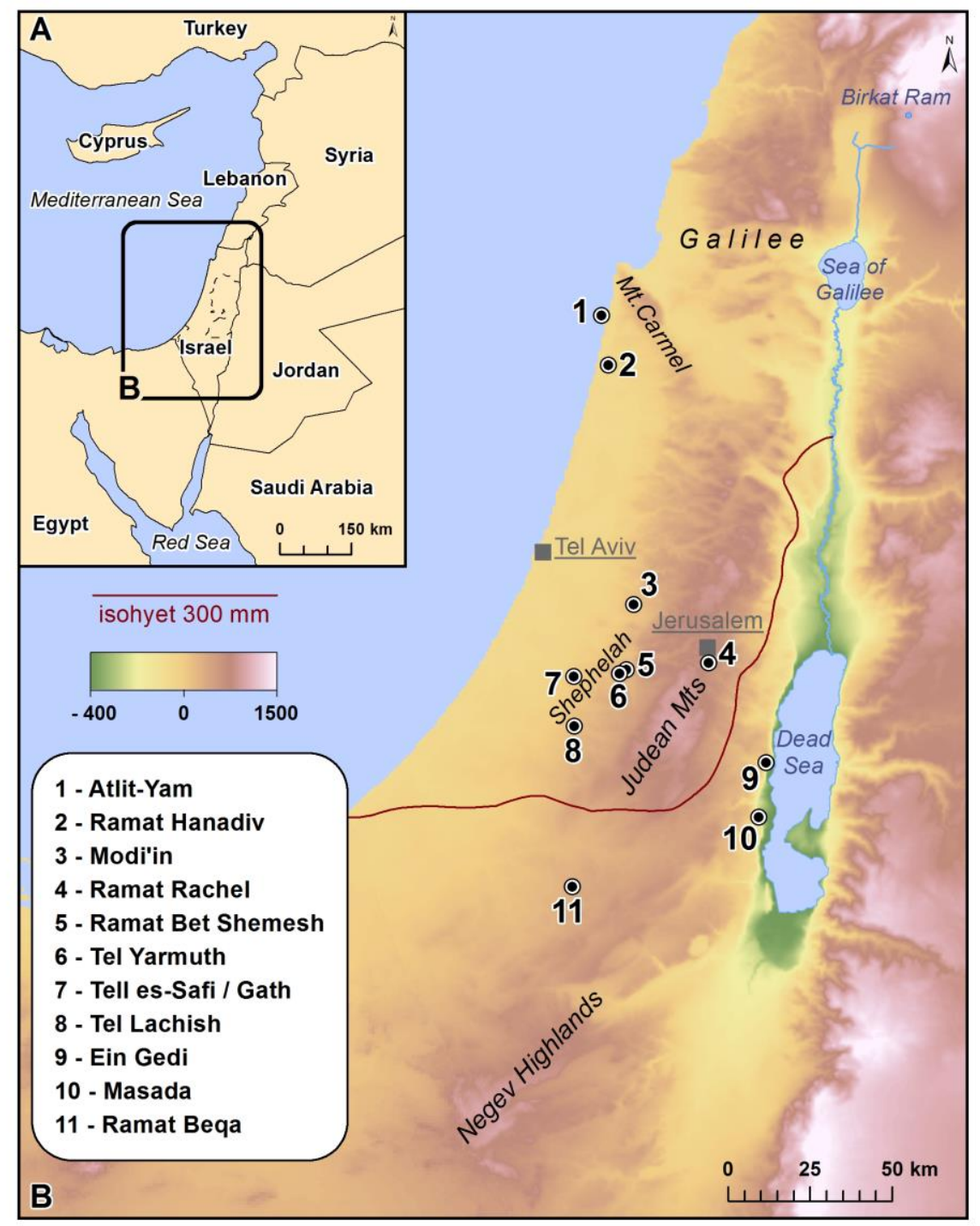


This region has seen intensive human activity for $\sim 1.5$ million years which attests to the earliest hominin sites; but in particular, during the past ca. 10,000 years, since the "Neolithic Revolution" (Horwitz et al., 1999; Weiss et al., 2004; Zohary et al., 2012; Marom \& Bar-Oz, 2013). The latter brought about far reaching changes to the landscape such as deforestation, intentional burning, establishment of cultivated fields and terraces, grazing regimes etc. (Naveh \& Dan, 1973). These human activities created a situation in which the ecosystem constantly had to adapt to human management and new interventions (Perevolotsky, 2005; Perevolotsky et al., 2013). This is manifested, for example, in the fast renewal of plant cover following decreased human activity (Perevolotsky \& Pollak, 2001; Shoshany \& Svoray, 2002, Svoray et al., 2003). In fact, human activity has become an integral part of the general ecosystem. Its long-lasting presence cannot be ignored (Naveh \& Carmel, 2004; Perevolotsky et al., 2013), suggesting that Israel is a "total human ecosystem" (Naveh, 2004).

\section{Physical Platform}

The ancient anthropogenic impact on the physical platform of Israel is expressed in: (a) archaeological site density of various types of settlements, including temporary camps, villages, hamlets and diverse urban entities. Given differences in scale and function, each settlement and installation type would have had a different impact on both its immediate environment and more distant locations (Goring-Morris \& Belfer-Cohen, 2011); (b) hewn landscapes, such as cupmarks in bedrock and stone quarries (e.g., Grosman \& Goren-Inbar, 2007; Dagan, 2011; Rosenberg \& Nadel, 2014; Grosman \& Goren-Inbar, 2016), wine and oil presses (Frankel, 2009), water wells, cisterns, water tunnels (Nir \& Eldar, 1986; Tsuk, 2011); (c) agricultural terraces (e.g., Ron, 1966; Gibson, 2001; Davidovich et al., 2012; Gadot et al., 2016); (d) anthropogenic soils comprised of, for example, human refuse and manure (Bruins \& Jongmans, 2012; Hadas, 2012; Shtienberg et al., 2017; Šmejda et al., 2017a,b; Paz et al., 2017); and (e) battlefield remains (e.g. Ackermann et al., 2005; Maeir, 2012; Lewis, 2015 ).

It should be noted that each site had an effect on its immediate surroundings resulting in "human niche" construction (Rowley-Conwy \& Layton, 2011) according to the site's function, size, settlement density, number of inhabitants, and level of technological knowledge (Tchernov \& Horwitz, 1991; Zeder, 2009; Perevolotsky et al., 2013; Kay \& Kaplan, 2015). Such effects occurred already in prehistoric times and are expressed by, amongst other things, natural resource depletion; the same factor is also implicated in societal collapse of later civilizations (Ponting, 1991; Diamond, 2002). For example, Rollefson \& Köhler-Rollefson (1992) have proposed that the collapse of settlements at the end of the Pre-Pottery Neolithic B period in the southern Levant (the beginning of the $6^{\text {th }}$ millennium $\mathrm{BCE}$ ) may be related to over-grazing and excessive use of wood for the lime plaster industry.

\section{(a) Archaeological Site and Installation Density}

The most prominent expression of human surface design is high site density over generations. Examination of this density using a simple count of settlement numbers spanning the Upper Paleolithic to Neolithic periods shows a diachronic trend of increasing quantities over time. This was interpreted as indicative of population growth, and is related to the advent of sedentism and food production (Fig. 2 in Goring-Morris \& Belfer-Cohen, 2011). However, peak demographic density in antiquity was only attained during the late Roman and Byzantine periods $\left(4^{\text {th }}-7^{\text {th }}\right.$ centuries CE) (Tsafrir, 1996). An example of high site density at this time is evident in the results of the southern Shephelah (Judean Foothills) 
Ackermann O., Maeir A. M., Frumin S., Svoray T., Weiss E., Zhevelev H.M., Kolska Horwitz L.: The Paleo-Anthropocene and the Genesis of the Current Landscape of Israel

regional survey (Dagan, 2006). In an area of $100 \mathrm{~km}^{2}$ (Fig. 2), 573 sites and installations dating to the Byzantine period were identified, giving a density of 5.73 sites per $\mathrm{km}^{2}$.

Fig. 2: Byzantine sites in the archaeological survey of the Southern Shephelah (map no. 7 in Dagan, 2006, Courtesy of the Israeli Antiquities Authority)

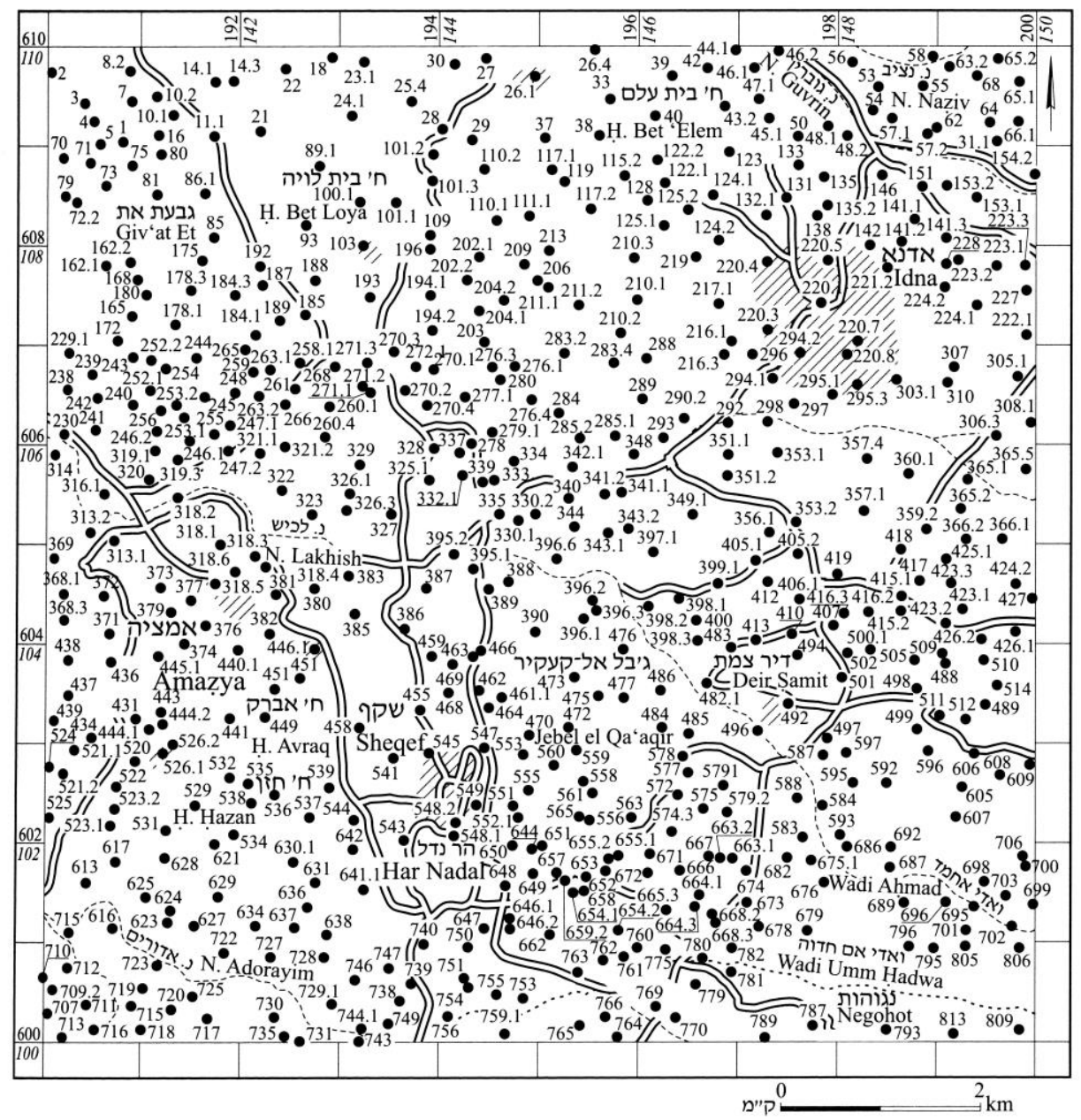

\section{(b) Hewn Landscape - Cup Marks and Quarries}

Ancient quarrying for tool making led to significant modifications of the bedrock form and shape. One of the first ancient effects on the landscape was the accumulation of waste flakes and stone debris (Barkai et al., 2002; Gopher \& Barkai, 2014). Large piles, up to $60 \mathrm{~m}$ wide and $40 \mathrm{~m}$ long, containing dumped limestone and flint quarry flakes, were observed by Rosenberg \& Nadel (2009) and Nadel et al., (2011) on Mount Carmel and dated to the Epipaleolithic Period (ca. 11,000 to 20,000 years ago). These stone dumps not only modified multiple aspects of the physical platform, but also created new micro-niches for plants and animals (Kaplan, 1984). 
Another example are cup marks (artificial hemispherical depressions or hollows cut into the bedrock) that have been associated with sites of different ages. The earliest intentionally made bedrock features are dated to the Natufian period (15,500-11,500 BP) (Filin et al., 2017). In the Shephelah (in the area of the modern city of Modi'in), cup marks were documented covering an area of $0.5 \mathrm{~km}^{2}$, and dated to the Pre-Pottery Neolithic A period (ca. 9600-8000 BCE) (Grosman \& Goren-Inbar, 2007, 2016). Another collection of rock-hewn installations was discovered by Dagan (2011) in his survey of the Ramat Bet Shemesh region, also in the Shephelah. In an area of $\sim 30 \mathrm{~km}^{2}$, Dagan revealed 3326 installations, of which 2283 were rock-hewn vats and 1034 were rock-hewn cup marks (Table 15.1 in Dagan, 2011,). This is a density of $\sim 110$ installations per $\mathrm{km}^{2}$. Grosman \& Goren-Inbar $(2007$; 2016) suggested that the Pre-Pottery Neolithic A cup marks were used to extract flint nodules for tool manufacturing; others suggest that these depressions were associated with food preparation (e.g., Eitam, 2009). These cup marks modify the rock surface and act as catchment points for water and soil, creating micro-environments for flora and fauna, as well as focal points for erosion and weathering (Allred, 2009).

Another type of ancient quarries are cube-shaped pits with sides up to $10 \mathrm{~m}$ high (Fig. 3) in depth. These quarries, from which stones were extracted for use in building, are found all over Israel and span many archaeological periods (e.g., Shiloh \& Horowitz, 1975).

Fig. 3: Ancient rock quarry in the Shephelah Region

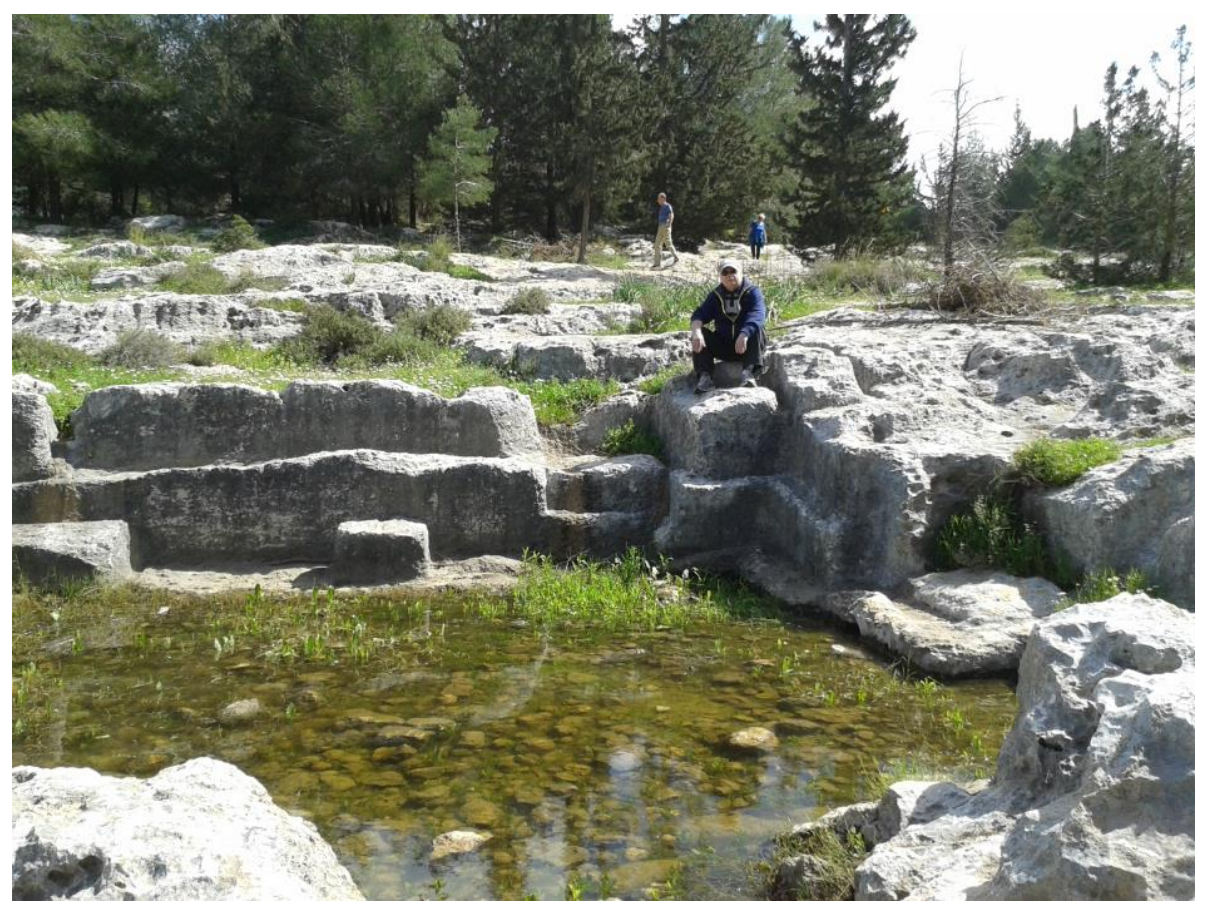

\section{(c) Agricultural Terraces}

The distribution of agricultural terraces is further evidence of the anthropogenic shaping of the landscape (Sayej, 1999). For example, in the Judean Mountains, Ron (1966) demonstrated that $56.4 \%$ of the slopes are covered with ancient agricultural terraces (Fig. 4). 
Ackermann O., Maeir A. M., Frumin S., Svoray T., Weiss E., Zhevelev H.M., Kolska Horwitz L.: The Paleo-Anthropocene and the Genesis of the Current Landscape of Israel

Recent OSL dating shows that most of the terraces were built during the Ottoman period (ca. 300-500 years ago) (Davidovich et al., 2012, Gadot et al., 2016), possibly on remnants of older terraces (Porat et al., 2017). In Ramat Bet Shemesh (Judean Foothills), Dagan (2011) showed that $89 \%$ of the area is covered by agricultural terraces located on wide valleys, stream beds and hillsides. Based on dating of ceramics found on the terraces, he suggested that these were primarily constructed during the Roman and Byzantine periods.

\section{Fig. 4: Agricultural terraces in the Judean Mountains}

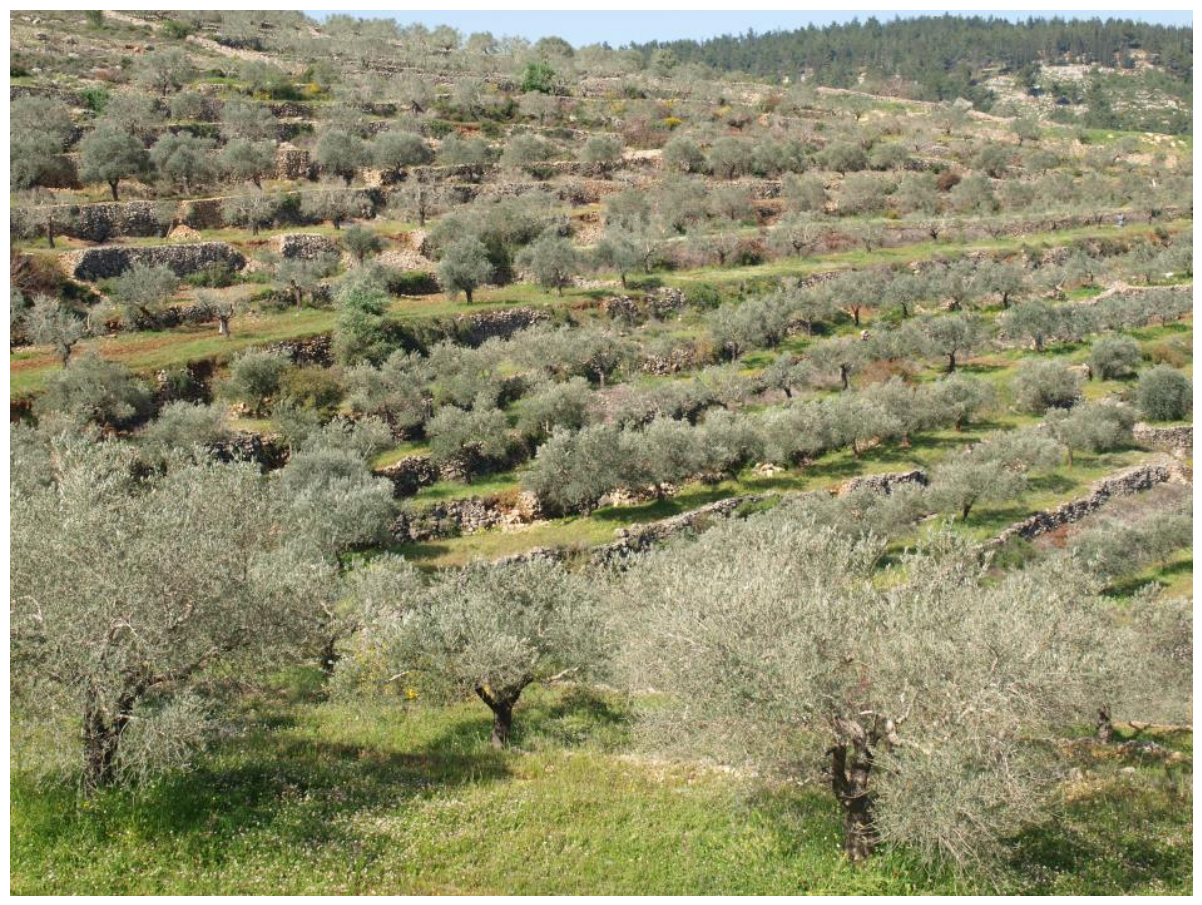

Another example of agricultural terracing is evident across the Negev Highlands (Fig. 5), where agricultural systems in an area of approximately $300 \mathrm{~km}^{2}$ were surveyed and documented (Haiman, 1995a; b). In this arid zone, with less than $100 \mathrm{~mm}$ of annual rainfall, runoff farming systems, based on water harvesting, were constructed. Small rock fragments were collected from the surface and placed in small heaps known as grape mounds or in Arabic "tuleilat el anab", in order to enhance runoff generation. Low channels on the slopes were built to increase the effectiveness of runoff transportation from the slopes to the agricultural fields in the valleys (Fig. 5; Lavee et al., 1997; Bruins \& Ore, 2008). These systems date to the Byzantine $\left(6^{\text {th }}\right.$ and $7^{\text {th }}$ centuries CE) and Early Islamic periods $\left(8^{\text {th }}-11^{\text {th }}\right.$ centuries CE) (Haiman, 1995a; 1995b; Avni et al., 2013). When these run-off systems were active, the landscape would have included tens to hundreds of orchards and vineyards, and been totally different from the current landscape. As Ashkenazi et al., (2015) found in the Negev Highlands, more than a hundred fruit trees planted by Bedouin in the early $20^{\text {th }}$ century survive without any human maintenance thanks to water that accumulates from old runoff harvesting systems. 
Changes in land use have resulted in the abandonment of many agricultural terraces, both in the Mediterranean region and the arid area of the Negev highlands, during the last 70 years. Terrace abandonment leads to the collapse of retaining walls and erosion of soil and sediments from the terrace body (Zgaier \& Inbar, 2005; Avni, 2005), with the latter occurring at a high rate in the arid Negev highlands (Avni, 2005). However, in the Judean Shephelah, an area under sub-humid Mediterranean conditions, the intensity of erosion is lower since abandoned terraces are covered by dense shrubs such as Sarcopoterium spinosum (Fig. 6, Ackermann et al., 2004, 2013) or by trees. This plant cover stabilizes and moderates the soil and sediment erosion. This regional climatic difference shows that the absence of terrace maintenance is more detrimental in the arid areas, which is more sensitive to erosion (Fig. 7) while in the Mediterranean area, which is more humid, dense plant coverage stabilizes the surface and conserves the soil and sediments within the terraces.

Fig. 5: Agricultural terraces in a runoff farm in the Negev Highlands and various installations on the slopes.

a. Stone heaps (tuleilat el anab) on the slope; b. Low channel; c. Water cistern; d. Pale heap made from sediment that was dumped from the water cistern; e. Check dam terraces

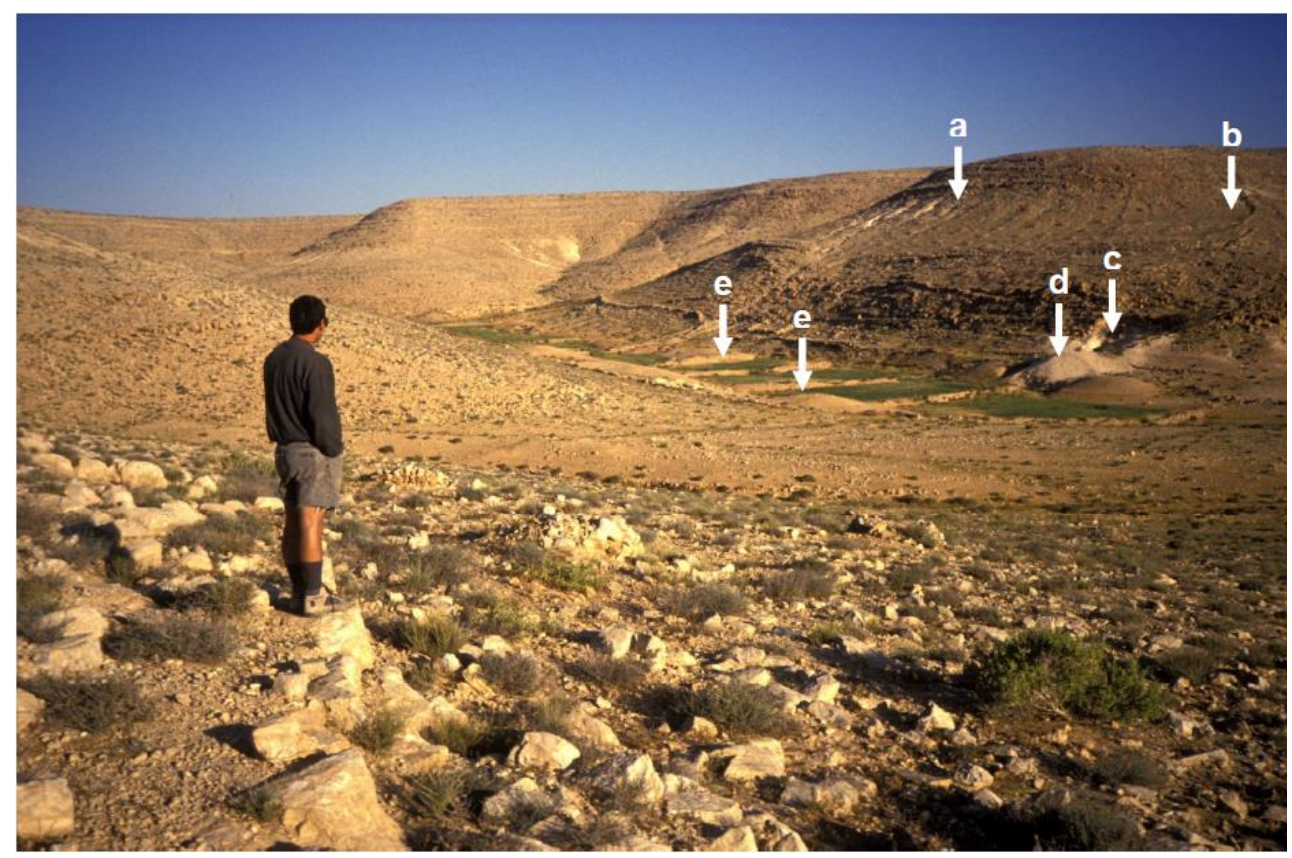


Ackermann O., Maeir A. M., Frumin S., Svoray T., Weiss E., Zhevelev H.M., Kolska Horwitz L.: The Paleo-Anthropocene and the Genesis of the Current Landscape of Israel

Fig. 6: Dense cover of Sarcopoterium spinosum $\mathrm{L}$. on an abandoned agricultural terrace in Ramat Bet Shemesh

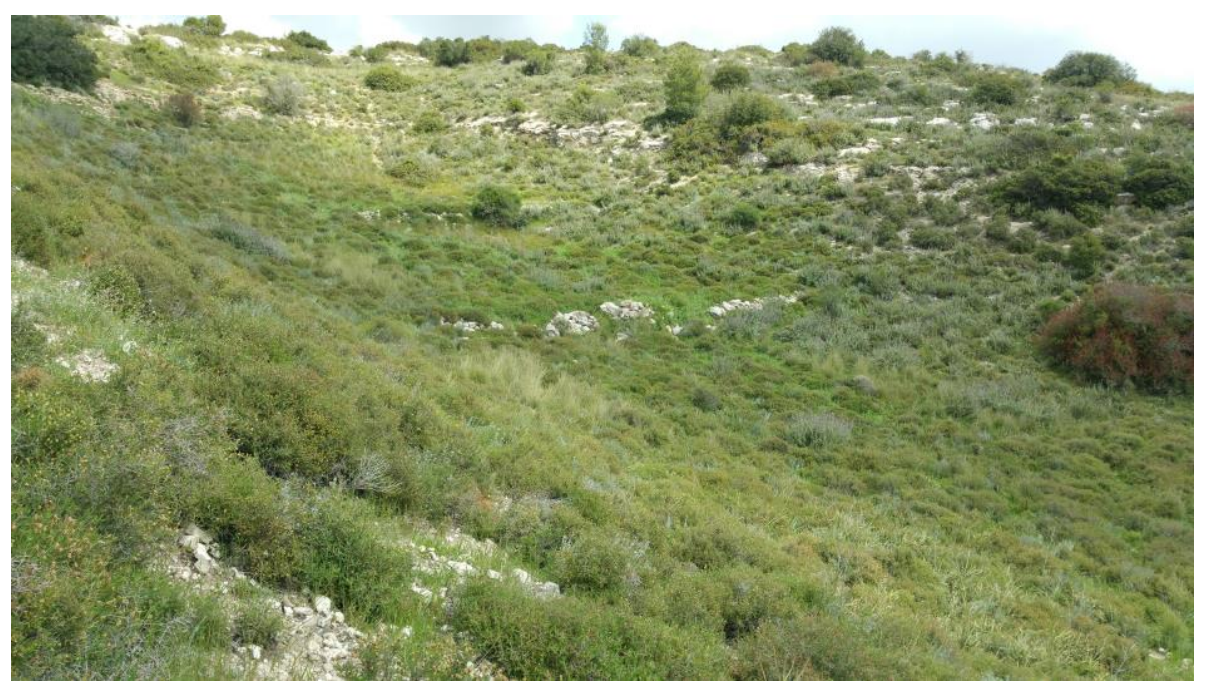

Fig. 7: Eroded abandoned agricultural terrace in the Negev Highlands

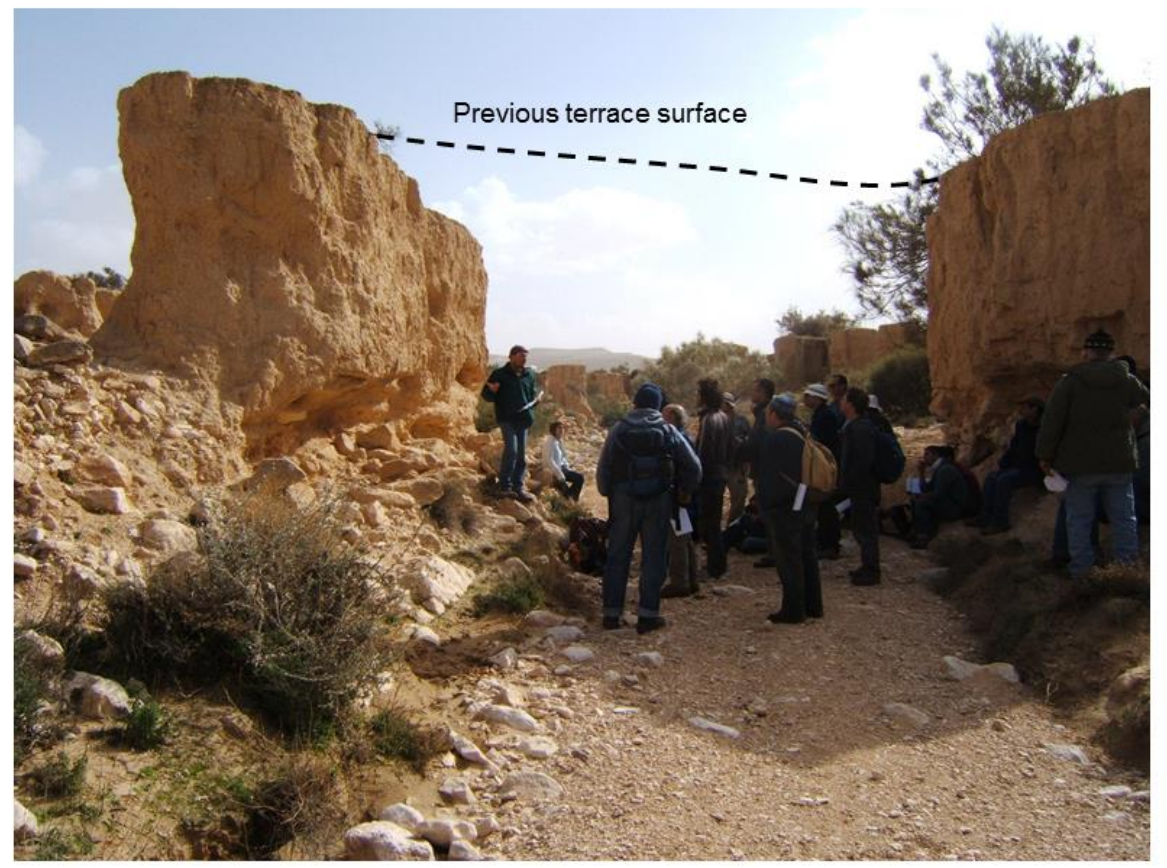




\section{(d) Anthropogenic Topography, Soil, Sediments and Rocks}

Construction of settlement mounds (tells) from the Early Bronze Age onwards (e.g. Maeir, 2012; Shai et al., 2012) led to significant changes in the general topography of Israel through the formation of artificial hills that reach heights of tens of meters above the immediate surroundings (Fig. 8) and extend the platform of natural hills with massive constructions comprised of fill (Finkelstein, 2011).

\section{Fig. 8: Tel Lachish, archaeological mound}

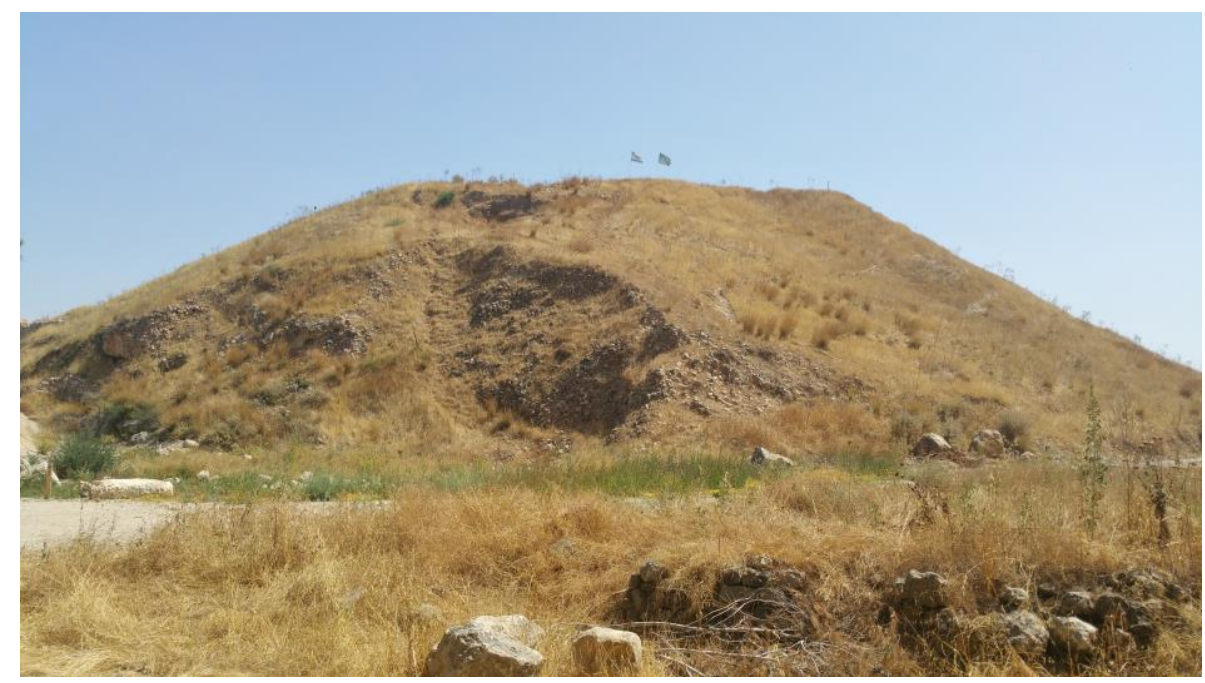

Tells contain accumulated remains of architecture, organic and material culture, soil and sediments that originate from remnants of stones and mudbricks, aeolian dust and sand, ceramic sherds, and house refuse (Rosen, 1986; Shahack-Gross, 2007). The latter enriches the sediments with key nutrients such as phosphorus $(\mathrm{P})$, potassium $(\mathrm{K})$, sulfur $(\mathrm{S})$, zinc $(\mathrm{Zn})$ and copper $(\mathrm{Cu})$ (Šmejda et al., $2017 \mathrm{a}, \mathrm{b})$, which has even resulted in the anthropogenic tell material being utilized as fertilizer by present-day traditional farmers (e.g., Wilkinson, 1989; Bailey, 1999; Dagan, 2011).

Anthropogenic soil was used to construct agricultural fields and terraces near Tel Yarmuth in the Shephelah during the Early Bronze Age III ( 2,200-2,700 BCE) (Paz et al., 2017), in the Dead Sea oasis of Ein Gedi during the Byzantine period $\left(5^{\text {th }}-6^{\text {th }}\right.$ centuries CE) (Hadas, 2012), and in the agricultural area on the coastal plain of Caesarea (Shtienberg et al., 2017a,b) and the Yavnah dunefield (Roskin \& Taxel, 2017). This soil was improved with homemade fertilizer from compost which included ash from ovens, animal and human excrement, and cultural material (fragments of pottery, glass and coins). Evidence for manuring of soil was found in ancient fields $\left(11^{\text {th }}-7^{\text {th }}\right.$ centuries BCE) by Bruins and Van Der Plicht (2014) in the runoff farms of the Negev. Micromorphological analyses of thin sections from anthropogenic soil at these sites showed the common presence of small fragments of ceramics as well as very small charcoal and bone fragments, some smaller than $0.01 \mathrm{~mm}$ in size, pointing to domestic refuse as the source of the fertilizer. In this case as well, soil fertilization carried out several thousand years ago still affects the chemical properties of the soil/sediments. Therefore, just as such sediments were used in the past as fertilizer, they continue to serve as nutrient banks for the current environment (Šmejda et al., 2017a,b). 
Ackermann O., Maeir A. M., Frumin S., Svoray T., Weiss E., Zhevelev H.M., Kolska Horwitz L.: The Paleo-Anthropocene and the Genesis of the Current Landscape of Israel

Human activities can lead to the formation of "Anthropo-calcrete" (Itkin et al., 2016). Anthropogenic influences on formation processes of calcrete pedogenesis can occur when humans generate or enhance calcium carbonate cementation in calcrete prone environments. It has been identified in several different contexts such as: (a) pedogenic calcification of lime-based building materials; (b) calcretic coatings on potsherds; (c) cementation of fragmented chalk embedded in an agricultural terrace; (d) biogenic cementation on exposed transition zone of the calcrete in an agricultural landform; (e) calcified human-made piles of waste carbonate materials; and (f) calcrete cementation of an archaeological mound's pedosediment.

Consolidated dumped chalky fragments were found buried in a few archaeological sites in the Shephelah; for example, in Tell es-Safi/Gath (Ackermann et al., 2012) and in the modern town of Modi'in. These buried fragments, under relatively high humidity, were compacted into an anthropogenic bedrock which contains ceramic shards (Fig. 9). Another example of anthropogenic sediment is documented from the Ramat Beqa quarry in the Negev and the hinterland of the ancient city of Caesarea, where researchers identified several events of Holocene reworking of the sands, which they interpreted as partly due to anthropogenic activities (Roskin et al., 2011, 2013, 2015; Shtienberg et al., 2017a,b).

Fig. 9: Anthropogenic rock; compacted dumped chalky fragments in Modi'in. Note: Arrows show embedded ceramic sherds (Photo taken with permission from Avraham Tandler, dig supervisor of the Israeli Antiquities Authority).

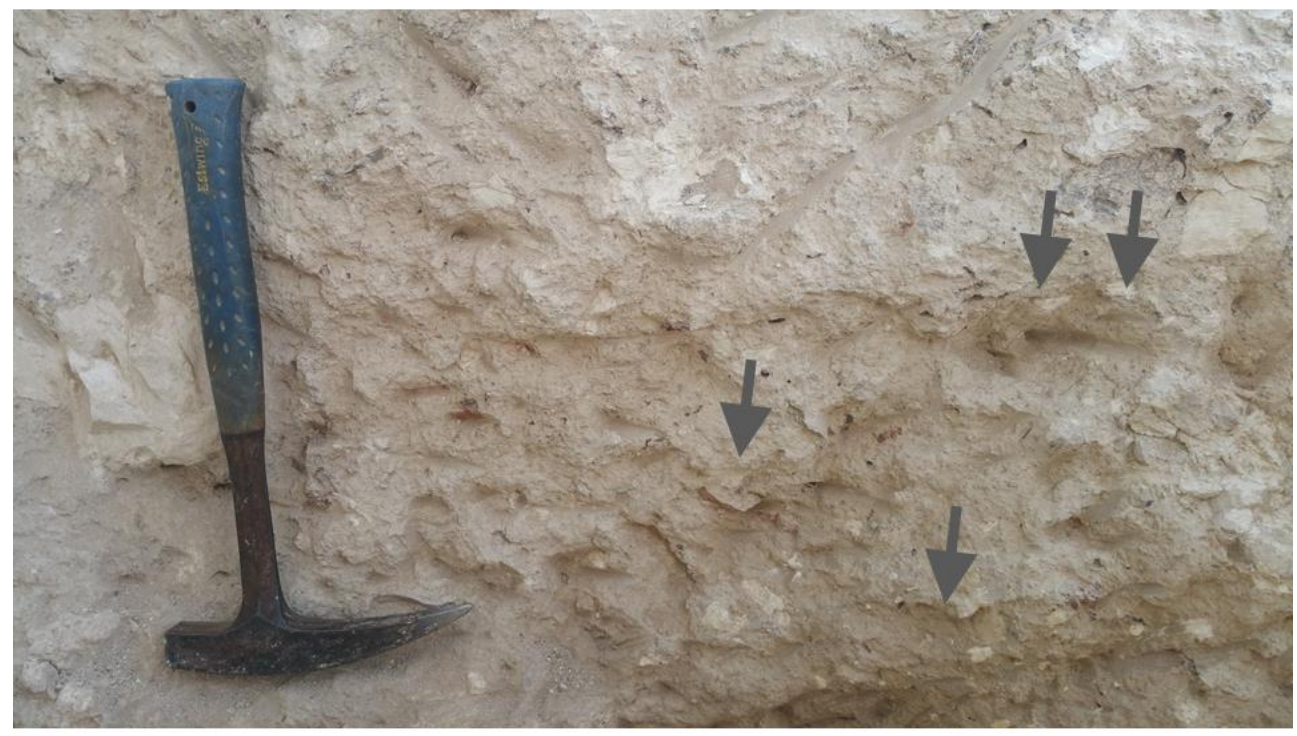

\section{(e) Battlefield Remains}

Many wars and battles have been fought in Israel, and some of them have had long-term impacts on the landscape (Lewis, 2015). An ancient siege system still visible today can be seen at Tell es-Safi/Gath, located in central Israel, and consists of an offensive trench, $2.5 \mathrm{~km}$ long and 5.5 meters deep (Ackermann et al., 2005; Maeir, 2012), probably constructed by Hazael the king of Aram during the $9^{\text {th }}$ century BCE. Both the trench and a berm formed from the excavated material significantly altered the original surface topography. The siege of 
ancient Tell es-Safi/Gath ended with the destruction of the city. In the subsequent period, materials eroded from the site, probably the remains of the mudbricks from the city's buildings, and collected in the valley at the foot of the site (Ackermann et al., 2014a; 2014b).

A similar phenomenon was documented by Rosen (1986) in neighboring Tel Lachish, where angular stones were found in the sediments in the adjacent Lachish channel, a result of the collapse of building walls following the destruction of the site by King Sennacherib of Assyria in 701 BCE. It seems, therefore, that the destruction of ancient cities and the collapse of their buildings contributed, in a relatively short period of time, to fill material which eroded and collected in the valleys below the sites, thereby altering the physical environment even further.

Another, more recent example, is the famous Roman siege system at Masada, at the Dead Sea, which included an assault ramp (Goldfus et al., 2006) and a $\sim 4.5 \mathrm{~km}$ long siege dyke which surrounded the site (Roth, 1995) and still stands today.

\section{Floral COMPOSITION \& DistribUTION}

\section{Current plant distribution patterns}

Depletion of trees and shrubs for firewood is a common problem in the Near East today (Arnold, 1979; Wickens, 1995), and there is good evidence from Israeli archaeological sites that this was also the case in the past. An example published by Lev-Yadun et al., (2010), presented both archaeobotanical and historical data in order to model the demands for wood, especially firewood, by the inhabitants of Masada from 150 BCE to 73 C.E., when it fell to the Roman X Legion following a siege. They presented data regarding optimal density of tree cover in the region of 90 per $\mathrm{km}^{2}$ at the time the site was occupied. They noted that in an arid region like Masada, given the size of the human population and intensity of exploitation, most trees and shrubs would have been eliminated around the site long before the Roman siege.

Humans have contributed to shaping the landscape resulting in significant changes in the pattern of plant distributions. Evidence for this was obtained during the study of the trench siege in Tell es-Safi/Gath, and in the mapping of modern plant cover in abandoned agricultural terraces in the Judean Shephelah (Fig. 6) (Ackermann et al., 2004; 2013). In both of these cases, the soil surface was altered by ancient anthropogenic activities. The rock outcrops that generate a high amount of runoff, were covered by sediments, which led to lower water availability for the vegetation. These conditions constitute the preferred habitat of dwarf-shrub such as Sarcopoterium spinosum, (thorny burnet) which covers $80 \%$ of these remains, compared with coverage of only ca. $30 \%$ over most of the undisturbed slopes in the area. This results from the plant being highly resistant to dry conditions (Alon \& Kadmon, 1996). Higher shrubs and trees with relatively lower drought resistance are concentrated in soil pockets between the rock exposures or in the walls of the agricultural terraces, where there is enhanced water availability and spots that are relatively protected from grazing and fires. Thus, activities of several millennia ago still affect plant distribution in this region.

Another example of pattern distribution change is the occurrence of the Quercus ithaburensis (Tabor Oak). In the past, this tree was commonly found on the coastal plain of Israel. However, its numbers dwindled as it was exploited for charcoal production, and its wood was used for tool production and the extraction of materials for tanning leather in historic times (Avitsur, 1976). Today, in the Yehudia Forest in the Golan Heights, these trees grow out of stone heaps (tumuli) and dolmens, remnants of burial structures dating to the Chalcolithic and Early Bronze Ages (the $5^{\text {th }}-4$ th millennium BCE). The cracks between the rocks of the dolmens and tumuli, as well as the spaces between the stones in the retaining 
Ackermann O., Maeir A. M., Frumin S., Svoray T., Weiss E., Zhevelev H.M., Kolska Horwitz L.: The Paleo-Anthropocene and the Genesis of the Current Landscape of Israel

walls of the agricultural terraces, constitute sheltered spots from fire and herd animals. The acorns which sprout in the open spaces between the tumuli and dolmens do not survive the dry summer and fires (Kaplan, 1984). With decreased human settlement and agricultural pressure in this region over the last 70 or so years, these anthropogenic locales constitute refuge spots for acorns, and serve as a source for the renewal of trees which have covered the area over a period of tens of years (Reisman-Berman et al., 2006) and which, in many cases, will continue to flourish for centuries.

\section{Archaeobotanical findings}

The beginning of agriculture is one of the major phenomena shaping the landscape of Israel. Processes related to this include the deforestation of natural plants and the intentional cultivation of domesticated species. In addition, a new ecological niche was created: the agricultural field, from which the original plant population was removed by the farmer (Hartmann-Shenkman et al., 2015). This offered an opportunity for plants that could adapt and compete over light, water and land resources. For example, archaeobotanical remains from Atlit-Yam, a site off the northern coast of Israel from the Pre-Pottery Neolithic C period (beginning of the $6^{\text {th }}$ millennium BCE), shows the existence of cultivated domesticated species [e.g. cereals: Triticum dicoccum, (emmer wheat), Triticum parvicoccum (small-grained wheat); Pulses: Lens culinaris (lentil) and Cicer arietinum (chickpea)]; alongside annual weeds simultaneous with the introduction of agricultural bug pests (Hartmann-Shenkman et al., 2015). This may be the beginning (or perhaps the establishment) of an evolutionary process in which weeds and other annual plants adapted both to the growing conditions of the agricultural field and to agricultural processing, adaptations which have survived to this day.

From both biogeographical and human geographical points of view, Israel is located within a natural corridor. This corridor has been a conduit for diverse human groups, flora and fauna over the ages. The arrival of groups in a new territory often results in the introduction of new plants. For example, with the appearance of the immigrant Philistine culture in the southern Levant at the beginning of the Iron Age, the introduction of several new plant species has been documented. These species, which included cumin (Cuminum cyminum), sycamore (Ficus sycomorus) and the opium poppy (Papaver somniferum), later became significant cultivars in local cultures (Frumin et al., 2013). Later, Assyrian invasions during the Iron Age brought apricot (Prunus armeniaca) and hackberry (Celtis australis) into the region (Frumin et al., 2015 citing Liphschitz et al., 1992; Simchoni \& Kislev, 2011). Even later examples come from the Persian period $\left(5^{\text {th }}-4^{\text {th }}\right.$ century BCE), with the introduction of citron (Citrus medica) and walnut (Juglans regia). The latter species are native to the region of modern-day Iran, and it seems likely that they were introduced by the Persians (Langgut, 2017; Langgut et al., 2013).

In addition to introducing foreign species into the local agricultural regime, the Philistine immigration was also associated with an extensive change in the composition of local plant species exploitation, with more than 70 new, locally occurring species being incorporated into anthropogenic habitats. It is therefore possible that the Philistine migration was accompanied by the introduction of new agronomic methods, which differed from those customarily used in Israel until that time (Frumin et al., 2015; Frumin, 2017).

\section{Pollen assemblage from lake sediments}

Studies of micro-botanical remains (pollen, charcoal, phytoliths) have shown how past human activities shaped the composition of plant species in Israel (e.g. Rosen, 1986; Lipschitz et al., 1989; Neumann et al., 2006, 2007, 2010; Cabanes et al., 2012). For example, 
Kaniewski et al., (2013) examined biological indicators (pollen grains, fern spores, micro-charcoal fragments, and dinoflagellate cysts) extracted from a continuous core drilled on the southern flank of Tel Akko, located on the northern Mediterranean coast of Israel. Through their research, they were able to illustrate the ecological impact of urbanization in the Early Bronze Age ( 2,000 BCE) on the environment surrounding the ancient site. This process was reflected in a loss of forested ecosystems and a concomitant increase in cultivated species in urban periods, as well as the expansion of urban-adapted shrub-steppe vegetation due to reduced availability of natural water in the environment as a result of increasing water-needs from human settlements.

Findings from cores from the bottom of Birkat Ram Lake in the Golan Heights (Neumann et al., 2007), the Sea of Galilee (Baruch, 1988) and the Dead Sea (Neumann at al., 2007, 2010) demonstrate that prior to the massive human intervention during the Iron Age (prior to 1200 BC), various oak species were common. Quercus ithaburensis was common in central Israel, while Quercus boisseri was common in northern Israel. With the increase in agricultural activity during the Iron Age (ca. 1200 - 586 BCE), a decrease in the occurrence of the oak species noted above was concurrent with an increase in olive trees (Olea europaea).

Based on pollen data as well as historical sources, the cultivation of olive trees in the region peaked during the Hellenistic, Roman and Byzantine periods $\left(4^{\text {th }}\right.$ century BCE $-6^{\text {th }}$ century $\mathrm{CE}$ ). The augmented frequencies of olive pollen correlate with an increase in human agricultural activity during these periods, as well as an increase in the occurrence of oil presses (Frankel, 2009). Olive pollen is extremely sensitive to changes in the conditions of the tree. Closely cultivated olive trees (for example, trees that have been pruned or had climbers removed) produce large amounts of pollen and high fruit yield, while untreated trees have lower amounts of pollen and fewer fruit. Treating abandoned olive trees increases the creation of pollen rather rapidly (Langgut et al., 2014). Therefore, high olive pollen signals are an extremely good indication for reconstructing agricultural practices in the past. Following the Byzantine period, with the transition to the early Islamic period (ca. $7^{\text {th }}$ century $\mathrm{CE}$ ), the quantity of olive pollen dropped, while the amount of natural/wild trees increased. The renewal of natural trees was expressed first by an increase in the values of pine (Pinus) pollen and later by an increase in the prevalence of Quercus calliprinos. The latter peaked during the Mameluke period and the beginning of the Ottoman period $\left(13^{\text {th }}-16^{\text {th }}\right.$ century $\mathrm{BCE}$ ), an extremely high occurrence compared with previous, pre-Roman periods.

From the above, we can see that human activity caused major changes to the composition of species; Quercus ithaburensis and Quercus boisseri were replaced by Quercus calliprinos; as an interim stage, there was a prevalence in pines, perhaps as a result of its capacity for speedy reproduction. Another finding arising from the analysis of pollen graphs (Neumann et al., 2007; 2010) is that the appearance of Sarcopoterium spinosum co-occurs with the increase in human activity during the Iron Age, simultaneous to the appearance of olive trees. Its appearance increases during the Roman and Byzantine periods and peaks in these later periods, showing that Sarcopoterium spinosum is a plant which accompanies human activity. Current observations in olive groves in the Judean Mountains show that there is thick cover of Sarcopoterium spinosum at the edges of olive orchards. It is possible that with increased deforestation and a decrease in available firewood, this plant became a readily available source for firewood (Avitsur, 1976). Sarcopoterium spinosum grows quickly, especially after being harvested or after bush fires (Henkin at al., 1999; Henkin \& Seligman, 2002). Therefore, it is feasible that these characteristics make it a plant that accompanies human activity. It seems that when there was a decrease in human activity and fields were abandoned (for example, following the Byzantine period in the $7^{\text {th }}$ century $\mathrm{CE}$ ), this plant 
Ackermann O., Maeir A. M., Frumin S., Svoray T., Weiss E., Zhevelev H.M., Kolska Horwitz L.: The Paleo-Anthropocene and the Genesis of the Current Landscape of Israel

became dominant. This conclusion also arises from observations made in abandoned terraces, where Sarcopoterium spinosum reaches coverage levels of up to $80 \%$ of the landscape (Fig. 6, Ackermann et al., 2004, 2013). It is important to note that thus far, researchers have agreed that Sarcopoterium spinosum constitutes a pioneer dwarf-shrub plant at times of renewal (Reisman-Berman et al., 2006). However, the analysis of findings of pollen studies presented above shows that this plant also served as a plant accompanying agriculture. Concurrent with a decrease in agricultural activity, we observe a decrease in the appearance of Sarcopoterium spinosum.

\section{FAUNAL COMPOSITION}

At the end of the Pleistocene, mass extinctions of large animals occurred in various areas worldwide - such as North America and Australia (Roberts et al., 2001; Barnosky et al., 2004; Doughty et al., 2010). In the Levant, in general, and in Israel, in particular, there was no such mass extinction, but rather a staggered and gradual extinction and extirpation of different species of macro- and micro-vertebrates. For example, Tchernov (1988) showed that elephants survived in Israel up to the mid-Pleistocene (the end of the Acheulean culture, ca. 250,000 years BP) while the rhinoceros survived up to the late Pleistocene (the Epipaleolithic Geometric Kebaran culture ca. 16,000 years BP). Extinctions of other large mammals, such as the hippopotamus, hartebeest and possibly lion, occurred even later, during the Iron Age (ca. 1200 - 586 BC; Horwitz \& Tchernov, 1990; Tsahar et al., 2009), an era that witnessed significant economic, geopolitical and social changes in the region. Even though the direct role of people in these extinctions has not yet been proven, given the archaeological record of this region, we can assume that destruction, division and disturbance of natural habitats, as well as the expansion of human settlements and agricultural activities, combined with hunting, contributed to contributed to their demise. The process was accelerated with the introduction of firearms into the area during the late- $19^{\text {th }}$-early $20^{\text {th }}$ centuries CE, with the extinction rate of several mammalian species, such as red deer (Cervus elpahus), Persian fallow deer (Dama dama mesopotamica), roe deer (Capreolus capreolus), Syrian ostrich, (Struthio camelus syriacus), Syrian bear (Ursus arctos syriacus) and Nile crocodile (Crocodylus niloticus), (Yom-Tov \& Mendelssohn, 1988).

Intially, anthropogenic environments that were created around permanent human settlements such as in the Epipaleolithic and Neolithic, cleared these areas of wildlife through intensive hunting and, in later periods, resource competition with domestic herds. At the same time, these new anthropogenic environments provided new and relatively protected ecological niches for some taxa, offering readily available food, water, and shelter as well as a relatively protected, predator-free environment. Examples of commensal species that enjoyed this new niche include the house mouse (Mus musculus), house sparrow (Passer domesticus) and red fox (Vulpes vulpes), whose numbers increased significantly in the first permanent settlements dating to the Natufian period $(\sim 12,500 \mathrm{BCE})$ (Tchernov, 1984; Yeshurun et al., 2009). Irrespective of whether these animals were pests or commensals, they were attracted to and evolved in these anthropogenic niches (Weissbrod et al., 2013; Belmaker \& Brown, 2016).

Perhaps the most dramatic event shaping the fauna of Israel was animal domestication, an event which comprised both autochtonous domestication of wild progenitors as well as the introduction of new domesticates into the region (Davis, 1982; Horwitz et al., 1999). Local domestication is suggested for goats (Capra hircus) from the wild bezoar goat (Capra aegagrus), cattle (Bos taurus) from the aurochs (Bos primigenius) and pigs (Sus scrofa dom.) 
from the wild boar (Sus scrofa fer.) (Horwitz, 1989; 2003). Domestic animals introduced into the region that were domesticated elsewhere include sheep (Ovis aries), likely introduced in the Late Pre-Pottery Neolithic B period (ca. 8500-8000 BP; Horwitz \& Ducos, 1998), the donkey (Equus asinus) who first entered the region, probably from Egypt, in the late Chalcolithic/Early Bronze Ages $\left(5^{\text {th }}\right.$ and $4^{\text {th }}$ millenia BCE; Grigson 2012; Milevski, 2016); the horse (Equus caballus) who first appeared in the Middle Bronze Age (early $2^{\text {nd }}$ millenium BCE; Clutton Brock, 1992), and the dromedary camel (Camelus dromedaries), probably brought to the region from Saudi Arabia during the Iron Age II $\left(10^{\text {th }}\right.$ century BCE; Sapir-Hen \& Ben-Yosef, 2013).

Today, invasive species constitute a significant global environmental threat, manifested in three main areas: (a) habitat changes that endanger other ecosystem components; (b) replacement of local species; and (c) threatening of local industries (Simberloff et al., 2013). There are many examples of ancient invasive species in Israel, species that were brought by humans both intentionally and accidentally. An interesting example is the importation of pigs into Israel, probably by migrating Philistines, during the $12^{\text {th }}$ century BCE. Examination of ancient DNA from pig bones found in various sites from three periods - pre-Philistine (Bronze Age), Philistine (Iron Age I) and post-Philistine (Iron Age II) - indicates a gradual shift from a local, Levantine haplotype to a European one (Meiri et al., 2013, Sapir-Hen et al., 2015). Apparently, domesticated pigs were translocated by the Philistine population, together with several exotic plants (as noted above). From the Iron Age II onwards, the European haplotype became dominant in the region. It seems that some "Philistine" pigs escaped to the wild and mated with the local wild boar, resulting in the dominance of the European haplotype among the Israeli wild boar, which is the situation today (Guiffra et al., 2000; Meiri et al., 2013). This case shows how an invading species can leave a mark on local animals, long after the disappearance of the culture responsible for its translocation.

\section{DISCUSSION}

A broad spectrum of past human activities over several millennia (most notably since the Neolithic period 12,000 years ago, see Table 1) have significantly shaped the components of the Israeli landscape, and still affect it today. This effect can be divided into three main characteristics: local, linear and spatial (Fig. 10). The local effect is expressed in the site itself, as it changes the chemical composition of the site's sediment (Fig. 10a). In the immediate surrounding, the effect is expressed by a change in the soil/sediment characteristics and concomitant floral and faunal changes, as well as due to the establishment of agricultural installations such as water wells, winepresses and olive presses (Fig. 10b). In the far surrounding, the effect is expressed, for example, in deforestation and grazing (Fig. 10c).

From the linear perspective, the effect is expressed in landscape through the construction of contour terraces along the slopes (Fig. 10d) and check dam terraces in the small valley bottoms (Fig. 10e). In cases where the channel has a strong flow, the agricultural fields are located adjacent to the floodplain channel (Fig. 10f). From the spatial perspective, the human presence on the landscape during ancient times was quite dense, and local and linear activities merged and overlapped, creating a complex and continuous pattern of human effects (Fig. 10g). 
Ackermann O., Maeir A. M., Frumin S., Svoray T., Weiss E., Zhevelev H.M., Kolska Horwitz L.: The Paleo-Anthropocene and the Genesis of the Current Landscape of Israel

Fig. 10: The human pattern effect on the landscape.

Local

a. Site: Including buildings, open yards, etc.

b. Site + immediate surroundings: Construction of various installations in proximity to the site (gray squares) and alterations in the chemical content of the soil/sediments.

c. Site + immediate + far surroundings: Grazing, wood cutting, etc.

\section{Linear}

d. Contour terraces: On the slopes (see also Fig. 4)

e. Check dam terraces: Along the bottom of small valleys (see also Fig. 5)

f. Agricultural plots: On the floodplains adjacent to channels with a high rate of water (stream or floods).

Spatial

g. The entire landscape system: Contains all types of patterns, in a complex structure that covers the entire landscape.

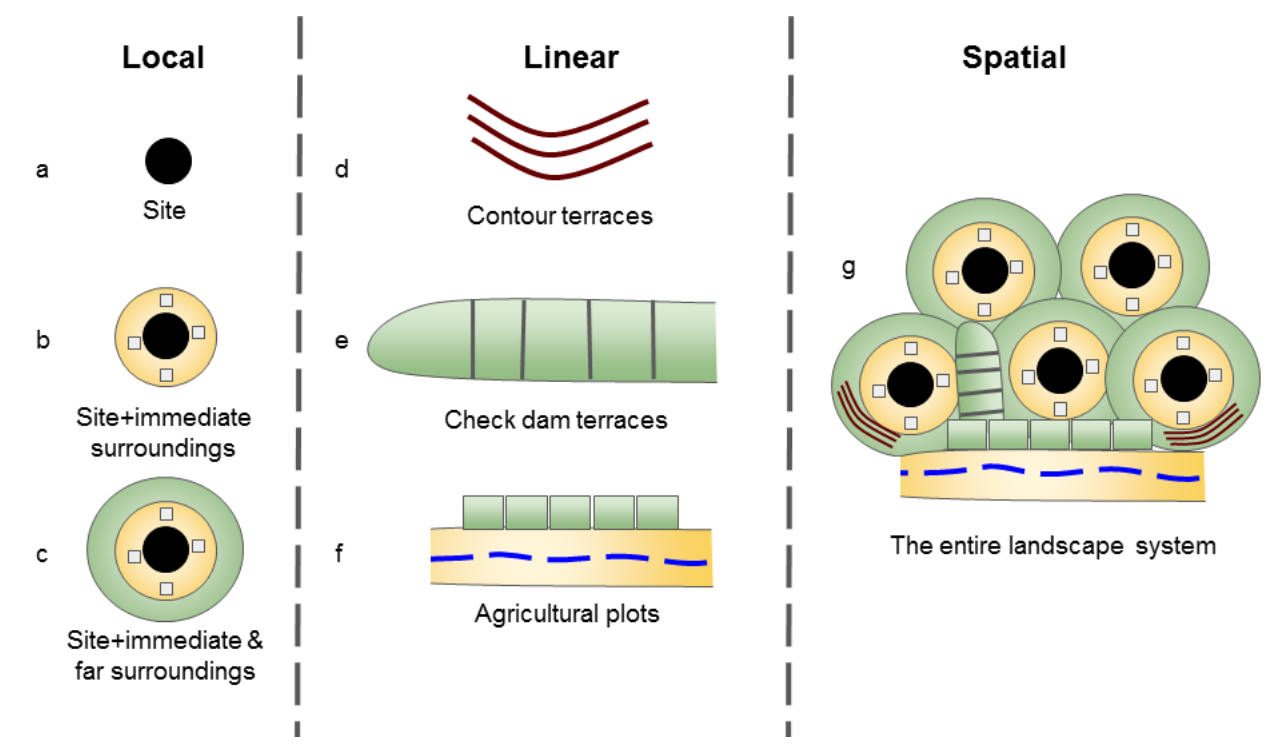

In fact, humans throughout generations have co-evolved with the landscape, in most instances directing the changes to the ecosystem (Perevolotsky et al., 2013). Accordingly, the following three-stage model of the development of the Israeli landscape system is proposed (Fig. $11 \mathrm{a}-\mathrm{c}$ ):

(a) The beginning of the Paleo-Anthropocene, when humans began to impact their environment on a small-scale;

(b) The later part of the Paleo-Anthropocene, when humans played a significant role in "designing" and directing their landscapes and ecosystems;

(c) The Anthropocene-periods of no direct human impact on the landscape, associated with the abandonment of settlements or agrarian systems. In such cases, humans are missing from the system; management, conservation and restoration of abandoned areas is essential. 
Fig. 11: Conceptual model - Phases in the Paleo-Anthropocene and Anthropocene landscape system.

a. The beginning of the Paleo-Anthropocene: Humans at the top of the pyramid with low activity and limited impact on the ecosystem.

b. The Paleo-Anthropocene develops: Human activities increase, as expressed in the extension of the upper level of the pyramid. Significantly modifies all aspects of the ecosystem; necessitates expanding the base of the pyramid and leads to the creation of a total humanecosystem .

c. The Anthropocene - Abandonment: Low levels of human activities and a lack of maintenance of traditional agrarian systems leads to deterioration. Deliberate management, in the form of conservation and restoration, is essential.

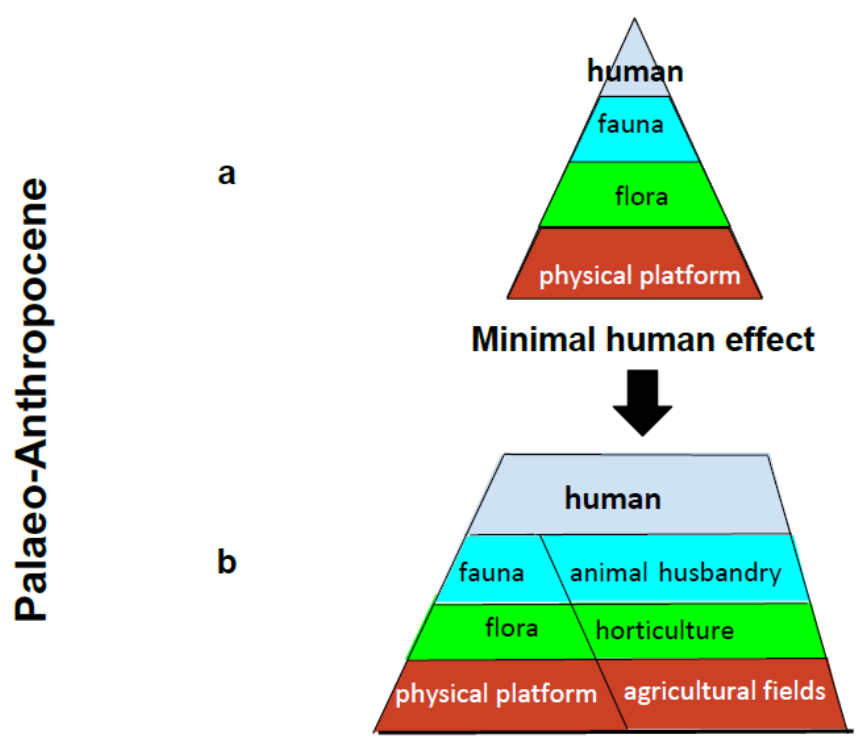

Human activity on a daily basis
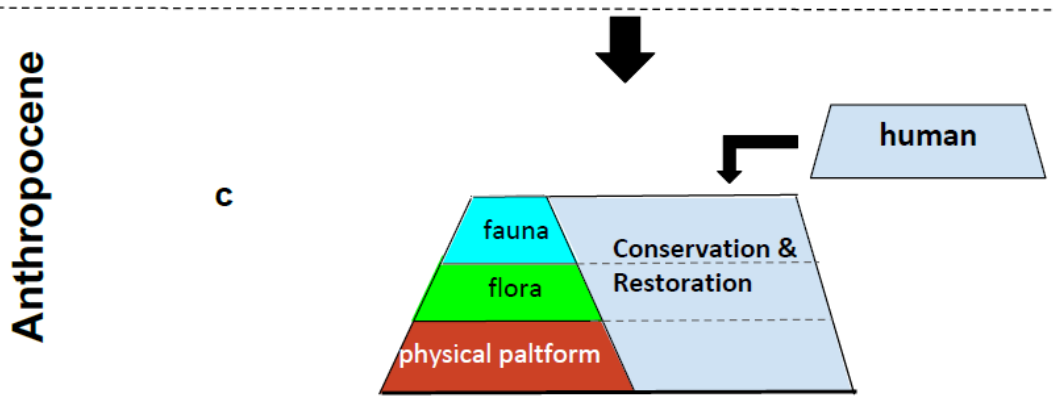

Abandonment

In the early stage of the Paleo-Anthropocene, humans were at the top of the ecological pyramid and the physical (geological/pedological) platform was at the base (Fig. 11a). This represents a point in time in which human activities had minimal impact on their environment. Over time, human impact increased, so that in order to maintain ecosystem 
Ackermann O., Maeir A. M., Frumin S., Svoray T., Weiss E., Zhevelev H.M., Kolska Horwitz L.: The Paleo-Anthropocene and the Genesis of the Current Landscape of Israel

stability, people had to expand the base of the pyramid by transferring materials and energy into the physical platform (Fig. 11b). This is expressed by the investment of labor/human energy in the expansion of the physical infrastructure through the construction of fields, agricultural terraces and water systems. These activities maximized the production capacity of the landscape system while increasing its viability such that over time, people in the region became a fully integrated part of the ecosystem (Pervolotzky, 2005; Naveh, 2004). Indeed, in the Mediterranean phytogeographic zone of Israel, the system in general exhibits adaptations to human intervention, as expressed by the fast renewal of plants following deforestation, grazing and fire (Naveh \& Dan, 1973; Pervolotzky \& Polack, 2001; Blondel, 2006).

In the third phase of the model (Fig. 11c), the Anthropocene, periods of system abandonment resulting from socio-political, economic and/or cultural changes lead to a deterioration of the ecosystem. The decrease in human activity would have allowed surface stabilization and regeneration of the wild vegetation. For example, in the Mediterranean region, renewed vegetation is characterized by dense coverage of dwarf shrubs which protect the physical platform from erosion and lead to surface stabilization in a "semi-frozen" state (Fig. 6). Dense coverage leads to low bio-diversity (Naveh \& Dan, 1973), which reduces the ecological health of the system and increases the risk of fires (Pervolotzky, 2005; Tessler et al., 2016). Recent changes in Israel have created a situation in which traditional agriculture has vanished from the landscape, leaving large areas without any human activity, resulting in reduced ecosystem resilience.

In the southern, arid areas of Israel, landscape and ecosystem abandonment is more critical, as the areas are highly sensitive to erosion processes due to limited plant coverage. Soil and sediment erosion might lead to a disappearance of the physical platform (Avni, 2005) which is the base of the pyramid. In such cases, the entire system is in danger of collapsing.

\section{Past skills as an inspiration for future management}

The current landscape system of Israel, as reflected in this discussion, is anthropogenic in origin. Generations of human activities have led to a point from which there is no return to the initial, "natural" form (Pervolotzky, 2005; Perevolotsky et al., 2013). Accordingly, human activities need to be considered as an integral part in shaping and maintaining the landscape. Since human activity in undeveloped areas has significantly decreased during the past few decades and has led to a deterioration of the landscape system, ongoing human management is vital to return the system to more efficient functioning of the region today (Fig. 11.c). This raises the question: 'What is the optimal required human management?'

Combined archaeological/ecological studies, together with research into traditional husbandry (ethnography), are needed to gain a deeper understanding of the inter-relations between these factors and how they have shaped the landscape. Human management should include an understanding of human skills and practices which were common in the past (such as the maintenance of terraces, small and heterogeneous fields, free-range herding, traditional plowing) and should be based on cumulative knowledge which maintained generations of human intervention in the ecosystem. One example of such human activity, which contributes to increased species biodiversity, was the utilization of an ancient plowing method in Ramat Hanadiv (in the Southern Carmel ridge), in an area which had not been tilled for approximately 50 years. Once the area was tilled with this method, several plant species, which were considered extinct in the region, reappeared (Schwartz-Tzachor et al., 2012).

The deteriorating situation of undeveloped areas in Israel stresses the need for the implementation of a novel methodology for the preservation of the anthropogenic landscape, which is in fact the natural landscape of the region. We propose that the long history of 
human experience and traditional knowledge, which created and maintained this landscape, can serve both as an inspiration, and a road map for future ecosystem management (e.g. Gadgil et al., 1993; Berkes et al., 2000; Menzies, 2006).

\section{SUMMARY AND CONCLUSIONS}

The landscape-ecosystem of Israel, being representative of the Eastern Mediterranean region in general, has been significantly affected by past human activity, in shaping its physical platform and in terms of species composition and spatial distribution patterns of flora and fauna (Table 1).

This is reflected in the surface design, modified by rock quarrying, constructions of agricultural fields and terraces, changes in the chemical composition of the sediments and the soils, and changes in the plant spacial distribution due to the physical and the chemical alternations of the rock, sediments and the soil.

Agricultural activity over the years has also caused a change in the composition of plant species, entry of weeds and of agricultural species. During periods of increased agricultural activity, it appears that the olive tree became a primary plant, while with the decline in agricultural activity, the wild vegetation returned to cover the surface, albeit with a different composition from previously.

Human influence is also expressed in the animal composition, such as the extinction and extirpation of species the evolution of commensals and the introduction of invasive species that became dominant, such as the European pig.

In fact, the current landscape is the outcome of a long history of human activity. Even after specific activities terminated, their imprint often remained on the system for hundreds or even thousands of years, leading to a "Total Human Ecosystem" (Naveh, 2004). Changes in land use in recent decades, have led to abandoned areas lacking the essential human component.

The abandoned landscape is a low functioning system (i.e., low biodiversity, under fire danger, etc.). In contrast, when under human management, it represents an effective system that maintains vitality and function. These insights are extremely important for the effective management of the ecological-landscape system, based on the renewal and reconstruction of past human activity and traditional knowledge. This concept, pioneered by Naveh (2004), in conjunction with the advancements in eco-landscape history described above, enable us to take this concept a few steps forward.

To summarize, it is possible to say that the roots of the current landscape and ecosystem shaping in Israel are located deep in the Paleo-Anthropocene. Given the long history of human activity in the region, both physical and cultural, we can safely say that in this region, no stone has been left unturned.

\section{ACKNOWLEDGMENTS}

This research was supported by following: the F.I.R.S.T. (Bikura) track of the Israel Science Foundation (ISF) (Grant \#32/11 to AMM, UW and LKH); the Israel Science Foundation (Regular Grant 100/13 to AMM); the Ashkelon Academic College; and the Koschitzky Family Foundation, of Bar-Ilan University to O.A. The authors wish to Dr. Mitia Frumin for drawing the maps. Joel Roskin and the anonymous reviewer are thanked for supportive comments and useful suggestions. 
Ackermann O., Maeir A. M., Frumin S., Svoray T., Weiss E., Zhevelev H.M., Kolska Horwitz L.: The Paleo-Anthropocene and the Genesis of the Current Landscape of Israel

\section{REFERENCES}

Ackermann O., Maeir, A. M., and Bruins, H. J., (2004). Unique human-made catenary changes and their effect on soil and vegetation in the semi-arid Mediterranean zone: a case study on Sarcopoterium spinosum distribution near Tell es-Safi/Gath, Israel. Catena, 57, 309-330

Ackermann, O., Bruins, H. J., and Maeir, A. M., (2005). A Unique Human-Made Trench at Tell es-Safi/Gath - Israel: Anthropogenic, Impact and Landscape Response. Geoarchaeology, 20(3), 303-327.

Ackermann, O., Greenbaum, N., Bruins, H.J. Bar-Matthews, M. Ayalon, A., Almogi-Labin, A., Schilman, B and Maeir A M. (2012). "The Environmental and Paleogeographical History of the Tell es-Safi/Gath over the Past Four Millennia". In A.M. Maeir, (Ed.). Tell es-Safi/Gath I (pp. 531-556): Report on the 1996-2005 Seasons. Ägypten und Alten Testament 69. Wiesbaden: Harrassowitz.

Ackermann, O., Zhevelev. H. M., and Svoray, T., (2013). Sarcopoterium spinosum from mosaic structure to matrix structure: Impact of calcrete (Nari) on vegetation in a Mediterranean semi-arid landscape. Catena, 101, 79-91. doi:10.1016/j.catena.2012.10.001

Ackermann, O., Greenbaum, N., Bruins, H.J., Porat, N., Bar-Matthews, M., Almogi-Labin, A., Schilman, B., Ayalon, A., Kolska-Horwitz, L., Weiss, E., and Maeir, A. M., (2014a). Palaeoenvironment and Anthropogenic Activity in the Southeastern Mediterranean since the mid-Holocene: The Case of Tell es-Safi/Gath, Israel. Quaternary International, 328-329, 226-243.

Ackermann, O., Greenbaum, N., Ayalon, A., Bar-Matthews, M., Boaretto, E., Bruins, H.J., Cabanes, D., Kolska-Horwitz L., Neumann, F., Porat, N., Weiss, E., and Maeir A.M., (2014b). Using palaeo-environmental proxies to reconstruct natural and anthropogenic controls on sedimentation rates, Tell es-Safi/Gath, eastern Mediterranean. Anthropocene. 8:70-82. doi:10.1016/j.ancene.2015.03.004

Allred, L. (2009). Enchanted Rock: A Natural and Human History. Austin: University of Texas Press.

Alon, G. and Kadmon R., (1996). Effect of successional stages on the establishment of Quercus Calliprinos in the east Mediterranean maquis. Israel Journal of Plant Science, 44: 335-345.

Amundson, R., Berhe, A. A., Hopmans, J. W., Olson, C., Sztein, A. E., \& Sparks, D. L. (2015). Soil science. Soil and human security in the 21st century. Science (New York, N.Y.), 348(6235), 1261071. doi:10.1126/science.1261071.

Arnold, J.E.M., (1979). Wood energy and rural communities. Natural Resources Forum 3 (3): 229-252. Blackwell Publishing Ltd.

Ashkenazi E., Chen Y., Avni Y.and Lavee S. (2015). Fruit trees' survival ability in an arid desert environment without irrigation in the Negev Highlands of Southern Israel. Israel Journal of Plant Sciences 62 (1-2, 5-16). Retrieved August, 2015 from http://dx.doi.org/10.1080/07929978.2014.895561

Avitsur, S., (1976). Man and his work. Carta and the Israel Exploration Society, Jerusalem (in Hebrew).

Avni, Y., (2005). Gully incision as a key factor in desertification in an arid environment, the Negev highlands, Israel. Catena, 63(2), 185-220.

Avni, G., Porat, N., and Avn, Y. (2013). Byzantine-Early Islamic agricultural systems in the 
Negev Highlands: stages of development as interpreted through OSL dating. Journal of Field Archaeology, 38(4), 332-346.

Bailey, D. M. (1999). Sebakh, sherds and survey. The Journal of Egyptian Archaeology, 211-218.

Balter, M. (2013). Archaeologists Say the 'Anthropocene' Is Here-But It Began Long Ago. Science, 340, 261-262. DOI: 10.1126/science.340.6130.261.

Barnosky, A. D., P. L. Koch, R. S. Feranec, S. L. Wing, and A. B. Shabel (2004). Assessing the causes of Late Pleistocene extinctions on the continents, Science 306(5693), 70-75

Barkai, R., Gopher, A. and La Porta, P. C. (2002). Palaeolithic landscape of extraction: flint surface quarries and workshops at Mt Pua, Israel. Antiquity, 76(293), 672-680.

Baruch, U. (1998). The late Holocene vegetational history of Lake Kinneret (Sea of Galilee), Israel. Paleorient, 12(2), 37-48.

Belmaker M. and Brown A. B. (2016). A New Look at "on Mice and Men": Should Commensal Species be Used as a Universal Indicator of Early Sedentism? In: N. Marom, R.Yeshurun, L. Weissbrod and G.Bar-Oz (eds). Bones and Identity. Zooarchaeological Approaches to Reconstructing Social and Cultural Landscapes in Southwest Asia (pp. 25-43). Oxbow Books, Oxford.

Berna F., Goldberg P., Horwitz L. K., Brink J., Holt S., Bamford M. and Chazan M. (2012). Microstratigraphic Evidence of in situ Fire in the Acheulean Strata of Wonderwerk Cave, Northern Cape Province, South Africa. PNAS 109 (20): E1215-E1220. doi:10.1073/pnas.1117620109

Berkes, F., Colding, J., \& Folke, C. (2000). Rediscovery of traditional ecological knowledge as adaptive management. Ecological applications, 10(5), 1251-1262.

Blondel, J., (2006). The 'design' of Mediterranean landscapes: a millennial story of humans and ecological systems during the historic period. Human Ecology, 34(5), 713-729.

Boivin, N. L., Zeder, M. A., Fuller, D. Q., Crowther, A., Larson, G.,Erlandson, J. M., Denham, T., Petraglia, M. D. (2016). Ecological consequences of human niche construction: Examining long-term anthropogenic shaping of global species distributions. Proceedings of the National Academy of Sciences, 113(23), 201525200. doi:10.1073/pnas.1525200113

Braje, T. J. and Erlandson, J. M. (2014). Looking forward, looking back: Humans, anthropogenic change, and the Anthropocene. Anthropocene, DOI: 10.1016/j.ancene. 2014.05.002.

Bruins, H. J., \& van der Plicht, J. (2014). Desert settlement through the Iron Age. In Levy, T., \& Bruins H. J. and Jongmans A. G. (2012). Micromorphology of ancient agricultural Terraces in the Negev Desert, Horvat Haluqim (Israel). Proceedings of the 14th International Working Meeting on Soil Micromorphology (pp. 292-295), Poch RM, Casamitjana M, Francis ML (Eds). Departament de Medi Ambient i Ciències del Sòl (UdL). Lleida, Spain.

Bruins, H. J., and Ore, G., (2008). Runoff from loess or bedrock? Hillslope geoarchaeology of ancient runoff farming systems at Horvat Haluqim and Har Eldad in the central Negev Desert. Israel Journal of Earth Sciences, 57(3), 231-247. doi:10.1560/IJES.57.3-4.231

Cabanes, D., Gadot, Y., Cabanes, M., Finkelstein, I., Weiner, S., \& Shahack-Gross, R. (2012). Human impact around settlement sites: a phytolith and mineralogical study for assessing site boundaries, phytolith preservation, and implications for spatial reconstructions using plant remains.Journal of Archaeological Science, 39(8), 2697-2705.

Certini, G., and Scalenghe, R., (2011). Anthropogenic soils are the golden spikes for the 
Ackermann O., Maeir A. M., Frumin S., Svoray T., Weiss E., Zhevelev H.M., Kolska Horwitz L.: The Paleo-Anthropocene and the Genesis of the Current Landscape of Israel

Anthropocene. The Holocene, 21(8), 1269-1274.

Corcoran, P. L., Moore, C. J., \& Jazvac, K. (2014). An anthropogenic marker horizon in the future rock record. GSA Today, 24(6), 4-8.

Crutzen, P. J. (2002a). The "Anthropocene”. Journal de Physique IV, 12, 1-5.

Crutzen, P.J., (2002b). Geology of mankind. Nature, 415, 23.

Crutzen, P. J., \& Stoermer, E. F. (2000). The “Anthropocene.” Global Change Newsletter 41, 17-18.

Clutton-Brock, J. (1992). Horse Power: A History of the Horse and the Donkey in Human Societies. Harvard University Press: Cambridge, MA.

Dagan, Y. (2006). Map of Amazya (109). Archaeological Survey of Israel. Jerusalem: Israel Antiquities Authority.

Dagan. Y. (2011). Agricultural activity in the The Ramat Bet Shemesh Region. In: Dagan Y. (editor). The Ramat Bet Shemesh Regional Project: Landscapes of Settlement from the Paleolithic to the Ottoman Period, IAA Reports, No. 47, Israel Antiquites Authority, Jerusalem, pp. 319-340.

Danin, A. (1988). Flora and vegetation of Israel. (In Y. Yom Tov and E. Tchernov: The Zoogeography of Israel (pp. 129-157). Dr. W. Junk Publishers. Dordrecht, Netherlands.

Davidovich, U., Porat, N., Gadot, Y., Avni, Y., and Lipschits, O., (2012). Archaeological investigations and OSL dating of terraces at Ramat Rahel, Israel. Journal of Field Archaeology, 37(3), 192-208. doi:10.1179/0093469012Z.00000000019

Davis, S. J. (1982). Climatic change and the advent of domestication: the succession of ruminant artiodactyls in the late Pleistocene-Holocene in the Israel region. Paléorient 8: $5-15$.

Diamond, J. (2002). Ecological collapses of pre-industrial societies. Pages 389-406 in G.B. Peterson, editor. The Tanner lectures on human values, Volume 22. The University of Utah Press, Salt Lake CIty, Utah, USA.

Doughty, C.E., Wolf, A., and Field, C.B., (2010). Biophysical feedbacks between the Pleistocene megafauna extinction and climate: The first human-induced global warming? Geophysical Research Letters, 37(15), n/a-n/a. doi:10.1029/2010GL043985

Eitam D. (2009). Cereals in the Ghassulian Culture in Central Israel: Grinding Installations as a Case Study. Israel Exploration Journal 59(1): pp. 63-79.

Filin, S., Miller, V., Rosenberg, D., \& Nadel, D. (2017). Intra-and inter-site high-resolution geometrical analyses of Natufian bedrock features. Quaternary International, 439(b), 94-107.

Finkelstein, I. (2011). Observations on the Layout of Iron Age Samaria. Tel Aviv, 38(2), 194-207.

Foley, S.F., Gronenborn, D., Andreae , M.O., Kadereit, J.W., Esper, J., Scholz, D., Pöschl, U., Jacob, D.E., Schöne, B.R., Schreg, R., Vött, A., Jordan, D., Lelieveld, J., Weller, C.G., Alt, K.W., Gaudzinski-Windheuser, S., Bruhn, K.C., Tost , H., Sirocko, F., Crutzen, P. J., (2013). The Palaeoanthropocene - The beginnings of anthropogenic environmental change. Anthropocene, 3, 83-88. doi:10.1016/j.ancene.2013.11.002

Frankel, R., (2009). Introduction. In: Ayalon, E., Frankel, R., and Kloner, A., (Eds.) Oil and Wine Presses in Israel from the Hellenistic, Roman and Byzantine Periods (pp. 1-18). Oxford, British Archaeological Reports International Series - 1972. 
Frumin, S. (2017). Invasion Biology Analysis in Archaeobotany - Philistines Culture at Tell eș-Ṣäfi/Gath as a Case Study, unpublished Ph.D. dissertation. Bar-Ilan University, Ramat-Gan.

Frumin, S., Maeir, A. M., Horwitz, L. K., \& Weiss, E. (2015). Studying ancient anthropogenic impacts on current floral biodiversity in the Southern Levant as reflected by the Philistine migration. Scientific reports, 5, 13308.

Frumin, S., Maeir, A. and Weiss, E. (2013). Weeds as an indicator for anthropogenic links of the past. The 16th Conference of the International Workgroup for Paleoethnobotany. Thessaloniki, 17- 22 June 2013. Retrieved July 5, 2015 from http://iwgp2013. web.auth.gr/images/ abstract\%20book\%20revised.pdf

Gadgil, M., Berkes, F., \& Folke, C. (1993). Indigenous knowledge for biodiversity conservation. Ambio, 151-156.

Gadot, Y., Davidovich, U., Avni, G., Avni, Y., Piasetzky, M., Faershtein, G. Golan, D. \& Porat, N. (2016). The formation of a Mediterranean terraced landscape: Mount Eitan, Judean Highlands, Israel. Journal of Archaeological Science: Reports, 6, 397-417.

Galili, E. and Nir, Y. (1993). The submerged Pre-Pottery Neolithic water well of Atlit-Yam, northern Israel, and its palaeoenvironmental implications. The Holocene, 3 (3),265-270.

Gibson, S., (2001). Agricultural terraces and settlement expansion in the highlands of early Iron Age Palestine: is there any correlation between the two? In: Mazar, A., (Ed.), Studies in the Archaeology of the Iron Age in Israel and Jordan (pp. 113-146). Sheffield, Academic Press, Sheffield.

Gopher, A., \& Barkai, R. (2014). Middle Paleolithic open-air industrial areas in the Galilee, Israel: The challenging study of flint extraction and reduction complexes. Quaternary International, 331, 95-102. doi:10.1016/j.quaint.2013.08.025.

Goldfus, H., Avni, Y., Albag, R., \& Arubas, B. (2016). The significance of geomorphological and soil formation research for understanding the unfinished Roman ramp at Masada. Catena, 164, 73-87.

Goren-Inbar, N., Alperson, N., Kislev, M. E., Simchoni, O., Melamed, Y., Ben-Nun, A., \& Werker, E. (2004). Evidence of hominin control of fire at Gesher Benot Yaaqov, Israel. Science, 304(5671), 725-727.

Goring-Morris, A.N., and Belfer-Cohen, A. (2011). Neolithization processes in the Levant. Current Anthropology, 52(S4), S195-S208.

Grassel, H. (2006). Climate Change,New Weather Extremes and Climate Policy. In: Ehler, E. and Krafft, T. (Eds.), Earth System Science in the Anthropocene (pp. 41-50). Springer, Berlin, Heidelberg.

Grigson, C. (2012). Size matters - donkeys and horses in the prehistory of the Southernmost Levant. Paléorient 38(1-2), 185-201.

Grosman, L., \& Goren-Inbar, N. (2007). "Taming” Rocks and Changing Landscapes. Current Anthropology, 48(5), 732-740.

Grosman, L., \& Goren-Inbar, N. (2016). Landscape Alteration by Pre-Pottery Neolithic Communities in the Southern Levant-The Kaizer Hilltop Quarry, Israel. PloS One, 11(3), e0150395.

Guiffra E. Kijas J. M. H., Amarger V., Carlborg O., Jeon J.-T. and Andersson L. (2000). The Origin of the Domestic Pig: Independent Domestication and Subsequent Introgression. Genetics 154, 1785-1791. 
Ackermann O., Maeir A. M., Frumin S., Svoray T., Weiss E., Zhevelev H.M., Kolska Horwitz L.: The Paleo-Anthropocene and the Genesis of the Current Landscape of Israel

Guthrie, R. D. (2003). Rapid body size decline in Alaskan Pleistocene horses before extinction, Nature, 426(6963), 169-171.

Hadas, G. (2012). Ancient agricultural irrigation systems in the oasis of Ein Gedi, Dead Sea, Israel. Journal of Arid Environments 86, 75-81.

Hartmann-Shenkman, A., Kislev, M.E., Galili, E., Melamed, Y., and Weiss, E., (2015). Invading a new niche: obligatory weeds at Neolithic Atlit-Yam, Israel. Vegetation History and Archaeobotany, 24(1), 9-18.

Haiman, M., (1995a). Agriculture and Nomad-State Relations in the Negev Desert in the Byzantine and Islamic Periods. Bulletin of the American Schools of Oriental Research, 297, 29-53.

Haiman, M., (1995b). An Early Islamic Period Farm at Nahal Mitnan in the Negev Highlands. Atiqot, 36, 1-13.

Henkin, Z., and Seligman, N.G., (2002). Encroachment rates of individual Sarcopoterium spinosum dwarf-shrubs in a subhumid Mediterranean environment. Journal of Mediterranean Ecology, 3, 15-22.

Henkin, Z., Seligman, N.G., Noy-Meir, I. and Kafkafi, U., (1999). Secondary succession after fire in a Mediterranean dwarf-shrub community. Journal of Vegetation Science, 10, 503-514.

Horwitz, L.K. (1989). A reassessment of caprovine domestication in the Levantine Neolithic: Old questions, new answers. In: I. Hershkovitz (ed.), People and Culture Change. Oxford: BAR International Series, 508 (i) Pp. 153-181.

Horwitz, L.K. (2003). Temporal and spatial variation in Neolithic caprine exploitation strategies: A case study of fauna from the site of Yiftah'el, (Israel). Paleorient, 29 (1), 19-58.

Horwitz, L.K. and Tchernov, E. (1990). Cultural and environmental implications of hippopotamus bone remains in archaeological contexts in the Levant. Bulletin of the American Society of Oriental Research, 280, 67-76.

Horwitz, L.K. and Ducos, P. (1998). An investigation into the origins of domestic sheep in the southern Levant. In: H. Buitenhuis, L. Bartosiewicz and A.M. Choyke (eds.), Archaeozoology of the Near East III. (Pp. 80-94). Groningen: ARC Publicaties.

Horwitz, L.K., Tchernov, E., Ducos, P., Becker, C., von den Driesch, A., Martin, L. and Garrard, A. (1999). Animal domestication in the Southern Levant. Paleorient 25 (2): 63-80.

Horowitz, A., Siedner, G. and Yosef, O. B. (1973). Radiometric dating of the Ubeidiya Formation, Jordan Valley, Israel. Nature, 242(5394), 186-187.

Itkin, D., Goldfus, H., \& Monger, H. C. (2016). Catena Human induced calcretisation in anthropogenic soils and sediments: Field observations and micromorphology in a Mediterranean climatic zone , Israel. Catena, 1-14. doi:10.1016/j.catena.2016.06.025

Kafle, H. K., \& Bruins, H. J. (2009). Climatic trends in Israel 1970-2002: warmer and increasing aridity inland. Climatic Change, 96(1-2), 63-77.

Kaniewski, D., Van Campo E., Morhange C., Guiot J., Zviely D., Shaked I., Otto T. and Artzy M. (2013). Early urban impact on Mediterranean coastal environments. NatureScientific Reports 3: 3540 DOI: 10.1038/srep03540.

Kaplan, Y., (1984). The ecosystem of the Yahudia Nature Reserve. Ph.D. Thesis, Agricultural University of Wageningen. Wageningen, The Netherlands. 
Kaplan, J.O., Krumhardt, K.M., Ellis, E.C., Ruddiman, W.F., Lemmen, C., and Goldewijk, K.K., (2010). Holocene carbon emissions as a result of anthropogenic land cover change. The Holocene, 21(5), 775-791.

Karkanas, P., Shahack-Gross, R., Ayalon, A., Bar-Matthews, M., Barkai, R., Frumkin, A., Gopher, A. \& Stiner, M. C. (2007). Evidence for habitual use of fire at the end of the Lower Paleolithic: Site-formation processes at Qesem Cave, Israel. Journal of Human Evolution, 53(2), 197-212.

Kay, A. U., \& Kaplan, J. O. (2015). Human subsistence and land use in sub-Saharan Africa, 1000BC to AD1500: A review, quantification, and classification. Anthropocene, 9, 14-32

Kolbert, E., 2014. The Sixth Extinction: An Unnatural History. Henry Holt and Company.

Langgut, D. (2017). The Citrus Route Revealed: From Southeast Asia into the Mediterranean. HortScience, 52(6), 814-822.

Langgut, D., Lev-Yadun, S., and Finkelstein, I. (2014). The Impact of Olive Orchard Abandonment and Rehabilitation on Pollen Signature: An Experimental Approach to Evaluating Fossil Pollen Data. Ethnoarchaeology, 6(2), 121-135. doi:10.1179/1944289014Z.00000000016

Langgut, D., Gadot, Y., Porat, N., and Lipschits, O. (2013). Fossil pollen reveals the secrets of the Royal Persian Garden at Ramat Rahel, Jerusalem, Palynology , 37(1), 115-129. DOI:10.1080/01916122.2012.736418

Leakey, R.E. and Lewin, R. (1996). The Sixth Extinction: Patterns of Life and the Future of Humankind. New York: Anchor Books.

Lavee, H., Poesen, J., \& Yair, A. (1997). Evidence of high efficiency water-harvesting by ancient farmers in the Negev Desert, Israel. Journal of Arid Environments, 35(2), 341-348.

Lev-Yadun S., Lucas D.S. and Weinstein-Evron M. 2010. Modeling the demands for wood by the inhabitants of Masada and for the Roman siege. Journal of Arid Environments 74: 777-785.

Lewis, R. (2015).“Crusader Battlefields: Environmental and Archaeological Perspectives”. In A.J. Boas (Ed.), The Crusader World (pp. 460-489). Routledge: New York.

Liphschitz, N., Waisel, Y., Fahn, A., Werker, E. \& Baruch, U. (1992). In Excavations at the City of David 1978-1985 Directed by Yigal Shiloh. Vol. III. Stratigraphic, Environmental, and Other Reports. Qedem 33 (eds de Groot, A. , \& Ariel, D.T.) 105-121 (Institute of Archaeology, The Hebrew University of Jerusalem.

Liphschitz, N., Gophna, R., \& Lev-Yadun, S. (1989). Man's impact on the vegetational landscape of Israel in the Early Bronze Age II-III. L'urbanisation de la Palestine à l'âge du Bronze ancien, 263-68.

Macklin, M. G., Fuller, I. C., Jones, A. F., \& Bebbington, M. (2012). New Zealand and UK Holocene flooding demonstrates interhemispheric climate asynchrony. Geology, 40(9), 775-778.

Maeir, A.M., (Ed.) (2012). Tell es-Safi/Gath I: The 1996-2005 Seasons. Ägypten und Altes Testament 69. Wiesbaden: Harrassowitz Verlag.

Marom, N. and Bar-Oz, G. (2013). The prey pathway: A regional history of cattle (Bos taurus) and pig (Sus scrofa) domestication in the northern Jordan Valley, Israel. PLoS One 8: 1-13; e55958.

Meiri, M., Huchon, D., Bar-Oz, G., Boaretto, E., Horwitz, L.K., Maeir, A.M., Sapir-Hen, L., Larson, G., Weiner, S., and Finkelstein, I., (2013). Ancient DNA and Population Turnover in 
Ackermann O., Maeir A. M., Frumin S., Svoray T., Weiss E., Zhevelev H.M., Kolska Horwitz L.: The Paleo-Anthropocene and the Genesis of the Current Landscape of Israel

Southern Levantine Pigs- Signature of the Sea Peoples Migration? Nature - Scientific Reports 3, 3035 (DOI: 10.1038/srep03035).

Milevski, I. (2016). Early Bronze Age Goods Exchange in the Southern Levant: A Marxist Perspective. Routledge.

Menzies, C. R. (Ed.). (2006). Traditional ecological knowledge and natural resource management. University of Nebraska Press.

Nadel, D., Rosenberg, D., Shtober-Zisu, N., Filin, S., (2011). The Nahal Galim / Nahal Ornit Prehistoric Flint Quarries in Mt. Carmel, Israel, Eurasian Prehistory, 8 (1-2), 51-66.

Naveh, Z. (2004). Epilogue: Toward a Transdisciplinary Science of Ecological and Cultural Landscape Restoration. Restoration Ecology 13 (1): 228-234.

Naveh, Z., and Dan, J., (1973). The human degradation of Mediterranean landscapes in Israel. In: di Castri, F., and Mooney, H.A., (Eds.), Mediterranean-Type Ecosystems (pp. 370-390), Origin and Structure. New York, Springer-Verlag.

Naveh, Z., and Carmel, Y., (2004). The evolution of the cultural Mediterranean landscape in Israel as affected by fire, grazing, and human activities. In: Wasser S.P., (Ed.), Evolutionary theory and processes: modern horizons (pp. 337-409.). Papers in Honour of Eviatar Nevo Springer Netherlands.

Neumann, F., Schölzel, C., Litt, T., Hense, A., and Stein, M., (2006). Holocene vegetation and climate history of the northern Golan heights (Near East). Vegetation History and Archaeobotany, 16(4), 329-346. doi:10.1007/s00334-006-0046-x.

Neumann, H.F., Kagan, E.J., Schwab, M.J., and Stein, M., (2007). Palynology, sedimentology and palaeoecology of the late Holocene Dead Sea. Quaternary Science Reviews, 26, 1476-1498. doi:10.1016/j.quascirev.2007.03.004.

Neumann, F.H., Kagan, E.J., Leroy, S.A.G., and Baruch, U., (2010). Vegetation history and climate fluctuations on a transect along the Dead Sea west shore and their impact on past societies over the last 3500 years. Journal of Arid Environments, 74(7), 756-764. doi:10.1016/j.jaridenv.2009.04.015.

Nir Y. and Eldar I. (1986). Ancient ground-water table in old wells as an indicator of paleo sea-levels and neotectonic changes along the coastal plain of Israel, Geological Survey of Israel Report GSI/34/86, 28 pp. (in Hebrew).

Paz, Y., Ackermann, O., Avni, Y., Ben-Hur, M., Birkenfeld, M., Langgut, D., Mizrahi, A.S., Weiss, E. and Porat, N. (2017). An early bronze age fertilized agricultural plot discovered near Tel Yarmouth, Ramat Bet Shemesh, Israel. Journal of Archaeological Science: Reports, 15, 226-234.

Perevolotsky, A. (2005). Integrating landscape ecology in the conservation of Mediterranean ecosystems: the Israeli experience. Israel Journal of Plant Sciences, 53(3-4), 203-213.

Perevolotsky, A., \& Pollak, G. (2001). Ecology theory and the Israeli experience, Jerusalem: Carta (in Hebrew).

Perevolotsky, A., Rosen, B., Rosenberg, D. (2013). Man as an ecological super-engineer in the Mediterranean forest. In A. Perevolotsky (Ed.). Conserving and managing Mediterranean ecosystems: The Ramat Hanadiv case study and beyond. Zichron Yaakov: Ramat Hanadiv (in Hebrew).

Ponting, C. (1991). A green history of the world: the environment and the collapse of great civilizations. Penguin, New York, New York, USA. 
Porat, N., Davidovich, U., Avni, Y., Avni, G., \& Gadot, Y. (2017). Using OSL Measurements to Decipher Soil History in Archaeological Terraces, Judean Highlands, Israel. Land Degradation \& Development.

Reisman-Berman, O., Kadmon, R., and Shachak, M., (2006). Spatio-temporal scales of dispersal limitation in the recolonization of a semi-arid Mediterranean oldfield. Ecography, 29(3), 418-426.

Ron, Z. (1966). Agricultural terraces in the Judean Mountains. Israel Exploration Journal, $16,33-49$.

Roberts R. G., Flannery T. F., Ayliffe L. K., Yoshida H., Olley J. M., Prideaux G. J., Laslett G. M., Baynes A., Smith M. A., Jones R., Smith B. L. (2001). New Ages for the Last Australian Megafauna: Continent-Wide Extinction About 46,000 Years Ago. Science, 292, 1888-1892.

Rollefson, G.O., and Köhler-Rollefson, I., (1992). Early Neolithic exploitation patterns in the Levant: Cultural impact on the environment. Population and Environment, 13, 243-254.

Rosen, M.A., (1986). Environmental change and settlement at Tel Lachish, Israel. Bulletin of the American Schools of Oriental Research, 263, 55-60.

Rosenberg, D., \& Nadel, D. (2009). Prehistoric flint quarries and workshops in Mount Carmel-The Nahal Galim/Nahal Ornit complex. The Quarry, 4(2), 5-12.

Rosenberg, D. and Nadel, D. (2014). The sounds of pounding: boulder mortars and their significance to Natufian burial customs. Current Anthropology, 55 (6), 784-812.

Roskin, J. and Taxel, I. (2017), April. Early Islamic inter-settlement agroecosystems in coastal sand, Yavneh dunefield, eastern Mediterranean coast, Israel. In EGU General Assembly Conference Abstracts (Vol. 19, p. 2391).

Roskin, J., Sivan, D., Shtienberg, G., Roskin, E., Porat, N., \& Bookman, R. (2015). Natural and human controls of the Holocene evolution of the beach, aeolian sand and dunes of Caesarea (Israel). Aeolian Research, 19, 65-85.

Roskin, J., Katra, I., \& Blumberg, D. G. (2013). Late Holocene dune mobilizations in the northwestern Negev dunefield, Israel: A response to combined anthropogenic activity and short-term intensified windiness. Quaternary International, 303, 10-23.

Roskin, J., Porat, N., Tsoar, H., Blumberg, D.G., Zander, A.M., (2011). Age, origin and climatic controls on vegetated linear dunes in the northwestern Negev Desert (Israel). Quaternary Science Reviews 30, (13-14), 1649-1674.

Roth, J. (1995). The length of the siege of Masada. Scripta Classica Israelica, 14, 87-110.

Rowley-Conwy, P., \& Layton, R. (2011). Foraging and farming as niche construction: stable and unstable adaptations. Philosophical Transactions of the Royal Society of London B: Biological Sciences, 366(1566), 849-862.

Ruddiman, W.F., (2003). The anthropogenic greenhouse era began thousands of years ago. Climatic Change, 61(3), 261-293.

Shahack-Gross, R. (2007). Approaches to understanding formation of archaeological sites in Israel: materials and processes. Israel Journal of Earth Sciences, 56(2-4), 73-86.

Sample, I., (2014). Anthropocene: is this the new epoch of humans? The Guardian, 16. Retrieved January 3, 2014 from http://www.theguardian.com/science/2014/oct/16/ -sp-scientists-gather-talks-rename-human-age-anthropocene-holocene.

Sapir-Hen, L., Meiri, M., \& Finkelstein, I. (2015). Iron Age pigs: new evidence on their origin and role in forming identity boundaries. Radiocarbon, 57(2), 307-315. 
Ackermann O., Maeir A. M., Frumin S., Svoray T., Weiss E., Zhevelev H.M., Kolska Horwitz L.: The Paleo-Anthropocene and the Genesis of the Current Landscape of Israel

Sapir-Hen, L., \& Ben-Yosef, E., (2013). The Introduction of Domestic Camels to the Southern Levant: Evidence from the Aravah Valley. Tel Aviv, 40(2), 277-285.

Sayej, G., (1999). The Origin of Terraces in the Central Hills of Palestine: Theories and Explanations. In: Abu-Lughod, I., Heacock, R., and Nashef, K., (Eds.), The Landscape of Palestine: Equivocal Poetry (pp. 201-210), Birzeit-Palestine, Birzeit University Publications.

Schwartz-Tzachor, R., Hadar, L., Perevolotsky, A. (2012). Prioritizing Conservation Efforts of Rare Species in Ramat Hanadiv Park as a case study. Ecology and Environment 3 (3), 220-229 (In Hebrew).

Shai, I., Cassuto, D., Dagan, A., \& Uziel, J. (2012). The fortifications at Tel Burna: date, function and meaning. Israel Exploration Journal, 141-157.

Shiloh, Y., \& Horowitz, A. (1975). Ashlar quarries of the Iron Age in the hill country of Israel. Bulletin of the American Schools of Oriental Research, (217), 37-48.

Shoshany, M., Svoray, T., (2002). Multidate adaptive unmixing and its application to analysis of ecosystem transitions along a climatic gradient. Remote Sensing of Environment, $82,5-20$.

Simberloff, D., Martin, J. L., Genovesi, P., Maris, V., Wardle, D.A., Aronson, J., Courchamp, F., Galil, B., García-Berthou, E., Pascal, M., Pyšek, P., Sousa, R., Tabacchi, E. and Vila, M., (2013). Impacts of biological invasions: what's what and the way forward. Trends in Ecology and Evolution, 28(1), 58-66.

Simchoni, O. \& Kislev, M. E. (2011). Early finds of Celtis australis in southern Levant. Vegetation History and Archaeobotany. 20: 267-271.

Šmejda, L., Hejcman, M., Horak, J., \& Shai, I. (2017a). Ancient settlement activities as important sources of nutrients $(\mathrm{P}, \mathrm{K}, \mathrm{S}, \mathrm{Zn}$ and $\mathrm{Cu}$ ) in Eastern Mediterranean ecosystemsThe case of biblical Tel Burna, Israel. CATENA, 156, 62-73.

Šmejda, L., Hejcman, M., Horak, J., \& Shai, I. (2017b, in press). Multi-element mapping of anthropogenically modified soils and sediments at the Bronze to Iron Ages site of Tel Burna in the southern Levant. Quaternary International.

Smith, B.D., \& Zeder, M.A., (2013). The onset of the Anthropocene. Anthropocene, 4, 8-13. Snir, A., Nadel, D., \& Weiss, E. (2015). Plant-food preparation on two consecutive floors at Upper Paleolithic Ohalo II, Israel. Journal of Archaeological Science, 53, 61-71.

Steffen, W., Sanderson, A., Tyson, P. D., Jäger, J., Matson, P. A., Moore III, B., \& Oldfield, F. (2004). Global change and the earth system: a planet under pressure. The IGBP Book Series. Berlin, Germany: Springer.

Steffen, W., Broadgate, W., Deutsch, L., Gaffney, O., \& Ludwig, C. (2015). The trajectory of the Anthropocene: the great acceleration. The Anthropocene Review, 2(1), 81-98.

Shtienberg, G., Dix, J. K., Roskin, J., Waldmann, N., Bookman, R., Bialik, O. M.,Porat, N., Taha, N. and Sivan, D. (2017a). New perspectives on coastal landscape reconstruction during the Late Quaternary: A test case from central Israel. Palaeogeography, Palaeoclimatology, Palaeoecology, 468, 503-519.

Shtienberg, G., Dix, J. K., Shahack-Gross, R., Yasur-Landau, A., Roskin, J., Bookman, R., Waldmann, N., Shalev, S. and Sivan, D. (2017b). Anthropogenic overprints on natural coastal aeolian sediments: A study from the periphery of ancient Caesarea, Israel. Anthropocene, 19, 22-34. 
Svoray, T., Shoshany, M., \& Perevolotsky, A. (2003). Mediterranean rangeland response to human intervention: a remote sensing and GIS study. Journal of Mediterranean Ecology, 4, 3-12.

Svoray, T., Ben-said S, (2010). Soil loss, water ponding and sediment deposition variations as a consequence of rainfall intensity and land use: a multi-criteria analysis. Earth Surface Processes and Landforms, 35, 202-216.

Svoray, T., Levi, R., Zaidenberg, R., Yaacoby, B. (2015). The effect of cultivation method on erosion in agricultural catchments: Integrating AHP in GIS environments. Earth Surface Processes and Landforms, 40, 711-725.

Tchernov, E., (1984). Commensal Animals and Human Sedentism in the Middle East. In: Clutton-Brock, J., and Grigson, C., (eds.), Animals in Archaeology 3. Early Herders and Their Flocks. BAR International Series, 202, 91-115. Oxford.

Tchernov, E., (1988). The biogeographical history of the southern Levant. In: Yom-Tov, Y., and Tchernov, E., (Eds.), The Zoogeography of Israel. Dordrecht: Dr. W. Junk Publishers. pp. 159-250.

Tchernov, E., \& Kolska Horwitz, L., (1991). Body size diminution under domestication: Unconscious selection in primeval domesticates. Journal of Anthropological Archaeology, 10 (1), 54-75.

Tessler, N., Wittenberg, L., \& Greenbaum, N. (2016). Vegetation cover and species richness after recurrent forest fires in the Eastern Mediterranean ecosystem of Mount Carmel, Israel. Science of The Total Environment, 572, 1395-1402.

Tsafrir, Y. (1996). Some Notes on the Settlement and Demography of Palestine in the Byzantine Period: The Archaeological Evidence. In Retrieving the Past, Essays on the Archaeological Research and Methodology in Honor of G. W. Van Beek, ed Joe. D. Seger. Winona Lake: Eisenbrauns: 269-83.

Tsahar, E., Izhaki, I., Lev-Yadun, S. and Bar-Oz, G., (2009). Distribution and Extinction of Ungulates during the Holocene of the Southern Levant. PloS One, 4(4), e5316.

Tsuk T. (2011). Water at the End of the Tunnel. Touring Israel's Ancient Water Systems. Jerusalem: Yad-Ben Zvi press (in Hebrew).

Vigne J-D. (2011). The origins of animal domestication and husbandry: A major change in the history of humanity and the biosphere. Comptes Rendu Biologies, 334, 171-181.

Voosen, P. (2016). Anthropocene pinned to postwar period. Science, 353 (6302), 852-853.

Weissbrod L., Kaufman D., Nadel D., Yeshurun R. and Weinstein-Evron M. (2013). Commensalism: Was it Truly a Natufian Phenomenon? Recent Contributions from Ethnoarcheology and Ecology. In Bar-Yosef O. and Valla F.R. eds. Natufian Foragers in the Levant. Ann Arbor, Michigan: International Monographs in Prehistory, Archaeological Series 19. Pp. 699-717.

Wickens G.E. (1995). Role of Acacia Species in the Rural Economy of Dry Africa and the Near East. FAO Organization.

Wilkinson, T. (1989). Extensive Sherd Scatters and Land-Use Intensity: Some Recent Results. Journal of Field Archaeology, 16, 31-46.

Weiss, E., Wetterstrom, W., Nadel, D., \& Bar-Yosef, O. (2004). The broad spectrum revisited: evidence from plant remains. Proceedings of the National Academy of Sciences of the United States of America, 101(26), 9551-9555.

Wrangham R. (2009). Catching Fire: How Cooking Made Us Human. Profile Books. 
Ackermann O., Maeir A. M., Frumin S., Svoray T., Weiss E., Zhevelev H.M., Kolska Horwitz L.: The Paleo-Anthropocene and the Genesis of the Current Landscape of Israel

Yeshurun, R., Bar-Oz, G., and Weinstein-Evron, M., (2009). The role of foxes in the Natufian economy: a view from Mount Carmel. Israel. Before farming, 1, 1-15.

Yom-Tov, Y., and Mendelssohn, H., (1988). Changes of the distribution and abundance of vertebrates during the 20th century in Israel. In: Yom-Tov, Y., and Tchernov, E., (Eds.), The Zoogeography of Israel (pp. 515-548). Holland, Dr. W. Junk Publishers.

Zohary, D., Hopf, M., and Weiss, E. (2012). Domestication of Plants in the Old World: The origin and spread of domesticated plants in Southwest Asia, Europe, and the Mediterranean Basin. New York, Oxford University Press.

Zeder M.A. (2009). The Neolithic macro-(r)evolution: Macroevolutionary theory and the study of culture change. Journal of Archaeological Research, 17, 1-63.

Zgaier, A., \& Inbar, M. (2005). The influence of soil saturation on the stability of abandoned agricultural hillslope terraces under Mediterranean climatic conditions. Developments in Earth Surface Processes, 7, 69-86. 